\title{
Distributions of krill and Antarctic silverfish and correlations with environmental variables in the western Ross Sea, Antarctica
}

\author{
L. Brynn Davis ${ }^{1, *}$, Eileen E. Hofmann ${ }^{1}$, John M. Klinck ${ }^{1}$, Andrea Piñones ${ }^{2,3,4}$, \\ Michael S. Dinniman ${ }^{1}$ \\ ${ }^{1}$ Center for Coastal Physical Oceanography, Old Dominion University, Norfolk, VA 23508, USA \\ ${ }^{2}$ Instituto de Ciencias Marinas y Limnológicas, Universidad Austral de Chile, Casilla 567, Valdivia 5090000, Chile \\ ${ }^{3}$ Centro de Investigación Dinámica de Ecosistemas Marinos de Altas Latitudes, Universidad Austral de Chile, \\ Valdivia 5090000, Chile \\ ${ }^{4}$ COPAS Sur-Austral, Universidad de Concepción, Concepción 4030000, Chile
}

\begin{abstract}
Antarctic krill Euphausia superba, crystal krill E. crystallorophias, and Antarctic silverfish Pleuragramma antarctica are key mid-trophic level species in the Ross Sea, connecting primary production to the upper trophic levels. Distributions of these species were constructed from observations made in the western Ross Sea from 1988 to 2004. Distributions of environmental conditions were obtained from a 5-km resolution circulation model (temperature, mixed layer depth, surface speed) and satellite-derived observations (chlorophyll, sea ice cover). A hierarchy of statistical methods determined correlations and relationships between species and environmental conditions. Each species occupies a localized habitat defined by different environmental characteristics. Antarctic krill are concentrated along the northwestern shelf break in a habitat characterized by deep $(>1000 \mathrm{~m})$ bottom depth, warm temperature $\left(1\right.$ to $\left.1.25^{\circ} \mathrm{C}\right)$, decreased sea ice, and proximity to the shelf break. Crystal krill and Antarctic silverfish are concentrated in Terra Nova Bay. Common characteristics of the habitat for these species are southwesterly location, coastal proximity, and cold temperature $\left(-1.75\right.$ to $\left.-2^{\circ} \mathrm{C}\right)$. The habitat characteristics obtained for the 3 species provide a basis for projecting potential distribution changes in response to environmental change and for delineating regions of the Ross Sea for focused management and selection of marine protected areas that support ecosystem-level conservation plans.
\end{abstract}

KEY WORDS: Antarctic krill · Euphausia superba $\cdot$ Crystal krill $\cdot$ E. crystallorophias $\cdot$ Pleuragramma antarctica $\cdot$ Habitat characteristics $\cdot$ Ross Sea $\cdot$ Antarctic

\section{INTRODUCTION}

The Ross Sea is among the most biologically productive regions within the Southern Ocean (Arrigo et al. 1998b, 2008), contributing about $35 \%(23.4 \pm 9.98$ $\mathrm{Tg} \mathrm{C} \mathrm{yr}{ }^{-1}[$ mean $\left.\pm \mathrm{SD}]\right)$ of the annual Southern Ocean

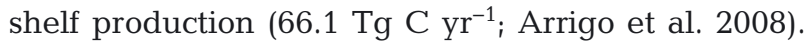
The primary production of the Ross Sea supports a complex and diverse food web that includes a suite of

${ }^{*}$ Corresponding author: LDavi062@odu.edu apex predators (Pinkerton et al. 2010, Ballard et al. 2012, Smith et al. 2012). Two species of krill (Antarctic Euphausia superba and crystal E. crystallorophias) and one fish species (Antarctic silverfish Pleuragramma antarctica) account for the majority of the mid-trophic level biomass in the Ross Sea and provide an important link between primary production and upper trophic levels (Daly \& Macaulay 1988, Ainley et al. 2006, Smith et al. 2007, Pinkerton et al. 2010).

() The authors 2017. Open Access under Creative Commons by Attribution Licence. Use, distribution and reproduction are unrestricted. Authors and original publication must be credited. 
Many of the apex predators (e.g. penguins, seals, and cetaceans), fish, and other mid-trophic level species in the Ross Sea depend directly or indirectly on krill and Antarctic silverfish as their primary food source (Pinkerton et al. 2010, Smith et al. 2012, Pinkerton \& Bradford-Grieve 2014). This dependency on a few mid-trophic level species sets up a food web structure in the Ross Sea in which these few species link and control energy flow between low and high trophic levels (Ainley et al. 2015). As a result, changes in distribution, abundance, and relative availability of these 3 species affect all trophic levels.

Crystal krill and Antarctic silverfish are associated with sea ice, which provides food and a nursery region for eggs and early life stages (Laws 1985, Kellermann 1986b, Daly \& Macaulay 1988), and these ice-obligate species tend to be found in neritic, ice-covered regions (Hubold 1984, Kellermann 1986a, Thomas \& Green 1988, Hosie 1991, Pakhomov \& Perissinotto 1996). For Antarctic krill, the presence of warm Circumpolar Deep Water (CDW) at depth is essential for completion of their early life history (Hofmann et al. 1992, Hofmann \& Hüsrevoğlu 2003), and this species tends to be found in regions where CDW is present (Quetin \& Ross 1984, Azzali \& Kalinowski 2000, Sala et al. 2002, Ashjian et al. 2004, Lawson et al. 2004). These general distributions exhibit considerable spatial variability between seasons and across the Southern Ocean (Azzali \& Kalinowski 2000, Siegel 2005, Lawson et al. 2008, Murphy et al. 2017). Studies have considered relationships between krill abundance and different environmental variables such as temperature, oxygen concentration, sea ice, and salinity (e.g. Witek et al. 1981, Weber et al. 1986, Siegel 2005, Atkinson et al. 2008, Murphy et al. 2017). However, predictable relationships that are stable between areas and years have yet to be determined, and the extent to which the distributions of this organism are related to environmental conditions is unknown. Understanding the factors influencing current krill and Antarctic silverfish distributions will allow projections of distributional changes in response to changing environmental conditions in the Ross Sea (e.g. Smith et al. 2014b).

The objectives of this study were to (1) construct distributions of the 3 key mid-trophic level species in the western Ross Sea and (2) evaluate the extent to which the distributions of these species are correlated with environmental variables. The first objective was addressed by constructing distributions of Antarctic krill, crystal krill, and Antarctic silverfish from historical literature. An optimized hot spot analysis was used to test the hypothesis that the species are or are not randomly distributed. The second objective was addressed by using an empirical orthogonal function analysis to establish statistically based quantitative relationships between species and environmental variables that are associated with the krill and silverfish habitat. Addressing these objectives provides guidance for understanding the effects of changes in mid-trophic level species on ecosystem processes and biogeochemical cycles in the Ross Sea.

\section{METHODS}

\section{Species' data sources}

The Italian Antarctic expeditions that took place in the western Ross Sea (Fig. 1A) between 1988 and 2000 provided extensive surveys of the distribution of Antarctic krill and crystal krill (Table 1, Fig. 1B). Krill sampling for juveniles and adults occurred during the austral summer (December to February) and late austral spring (November) and extended from $64^{\circ}$ to $77.5^{\circ} \mathrm{S}$ and from $177^{\circ} \mathrm{W}$ to $165^{\circ} \mathrm{E}$ (Fig. 1B). Antarctic silverfish surveys were made between 1988 to 2004 as part of cruises that extended from $67^{\circ}$ to $78^{\circ} \mathrm{S}$ and from $175^{\circ} \mathrm{W}$ to $164^{\circ} \mathrm{E}$ during the austral late spring and summer (Table 2, Fig. 1C). The abundance data for Antarctic silverfish include the larval, postlarval, and juvenile early life history stages. The aggregated krill biomass and silverfish abundance distributions reported from the cruises listed in Tables 1 \& 2, respectively, were digitized and converted to common units of biomass ( $\mathrm{t} \mathrm{km}^{-2}$ ) and abundance (ind. $\left.\left[1000 \mathrm{~m}^{3}\right]^{-1}\right)$, respectively. Details of how the biomass and abundance distributions were constructed from the acoustic and net-based observations are provided in the references listed in Tables $1 \& 2$.

\section{Environmental data sources}

The average maximum temperature below $300 \mathrm{~m}$ for the summer season of 2010 (Table 3, Fig. 2A) was extracted from simulated circulation distributions obtained from a 5-km horizontal resolution implementation of the Regional Ocean Modeling System (ROMS) for the Ross Sea (Mack et al. 2017). The 300-m temperature distribution provides a tracer for CDW which does not exhibit seasonal variations (Dinniman et al. 2003).

Ocean color measurements (Table 3) from the Seaviewing Wide Field-of-view Sensor (SeaWiFS) from 


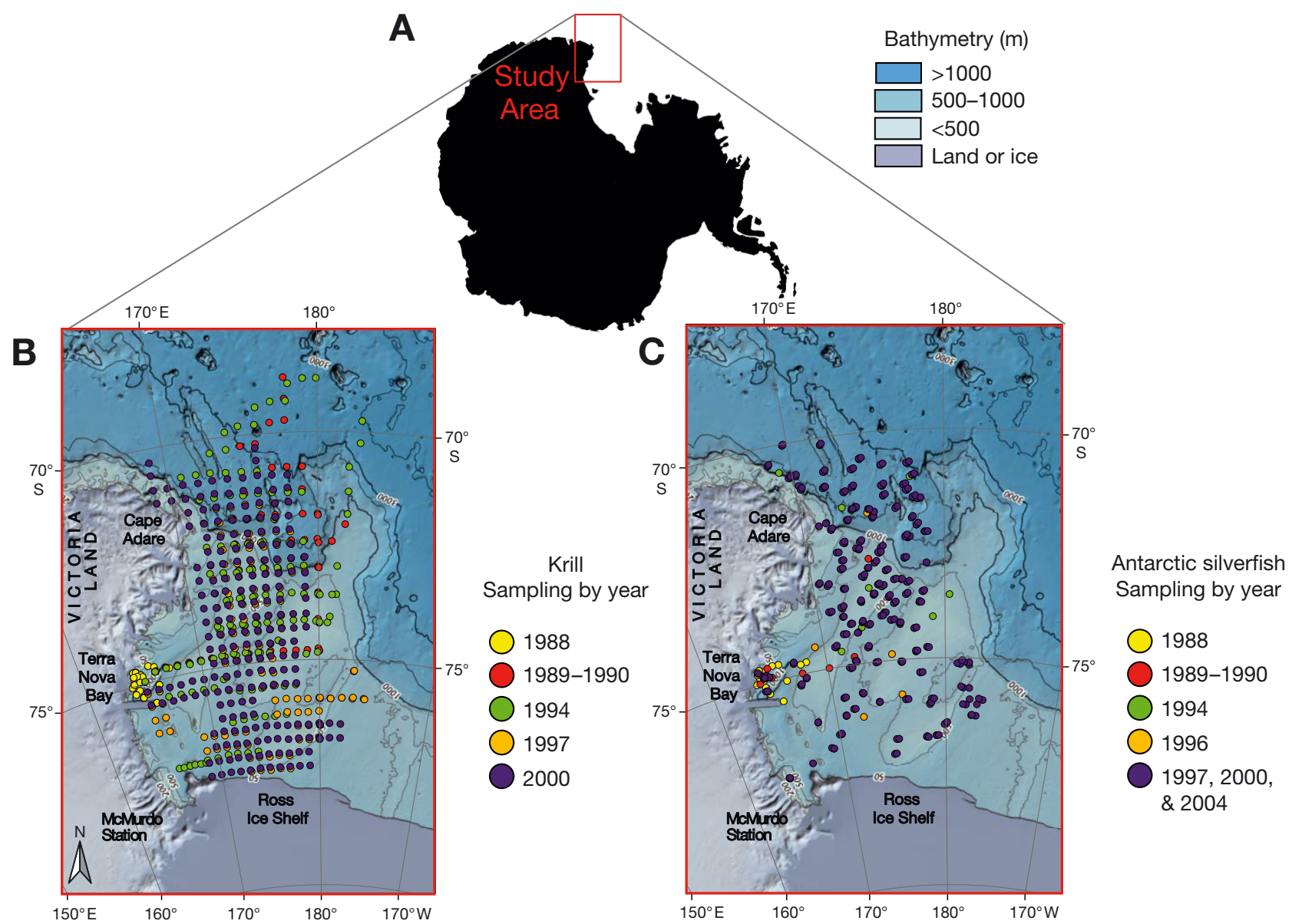

Fig. 1. (A) Antarctica, showing the study region in the western Ross Sea and maps of the sampling distributions by year for (B) krill (Euphausia superba and E. crystallorophias) and (C) Antarctic silverfish Pleuragramma antarctica. Bottom bathymetry data are from NOAA National Centers for Environmental Information; International Bathymetric Chart of the Southern Ocean; General Bathymetric Chart of the Oceans

September 1997 to April 2002 were obtained as part of the Processes Controlling Iron Regulation at the Mesoscale (PRISM) project that focused on the Ross Sea (McGillicuddy et al. 2017). Chlorophyll concentrations $\left(\mathrm{mg} \mathrm{m}^{-3}\right)$ estimated from SeaWiFS $8 \mathrm{~d}$ Level 3 binned seasonal climatology files were used to construct an average growing season (December to February) climatology (Fig. 2B).

Mixed layer depth (MLD; Table 3) was extracted from simulated circulation distributions for September 2010 to February 2012 (Mack et al. 2017). The MLD, defined as the depth where density $\left(\sigma_{t}\right)$ differs from

Table 1. Summary of cruise dates, species sampled, life history stage, units, and reference for the Italian Antarctic Expeditions to the western Ross Sea that provided the krill biomass data sets used in this study. The data sources were screened to avoid duplicate reporting of biomass data sets. nm: nautical mile

\begin{tabular}{|llccc|}
\hline Cruise date & Species sampled & Life history stage & Units & Reference \\
\hline January-February 1988 & Euphausia crystallorophias & Juvenile \& adult & ind. m ${ }^{-2}$ & Guglielmo et al. (2009) \\
December 1989 - January 1990 & E. superba & Adult & $\mathrm{t} \mathrm{nm}^{-2}$ & Azzali \& Kalinowski (2000) \\
November 1994 & E. superba & Adult & $\mathrm{t} \mathrm{nm}^{-2}$ & Azzali \& Kalinowski (2000) \\
December 1994 & E. superba \& E. crystallorophias & Adult & $\mathrm{t} \mathrm{nm}^{-2}$ & Azzali \& Kalinowski (2000) \\
November 1994 & E. superba \& E. crystallorophias & Adult & $\mathrm{t} \mathrm{km}^{-2}$ & Azzali et al. (2006) \\
December 1994 & E. superba \& E. crystallorophias & Adult & $\mathrm{t} \mathrm{km}^{-2}$ & Azzali et al. (2006) \\
December 1997 & E. superba \& E. crystallorophias & Juvenile \& adult & $\mathrm{t} \mathrm{km}^{-2}$ & Azzali et al. (2006) \\
January 2000 & E. superba \& E. crystallorophias & Juvenile \& adult & $\mathrm{t} \mathrm{km}^{-2}$ & Azzali et al. (2006) \\
January-February 2000 & E. superba \& E. crystallorophias & Juvenile \& adult & ind. (1000 m $)^{-1}$ Sala et al. (2002) \\
\hline
\end{tabular}


Table 2. Summary of cruise dates, life history stage, units, and references for the Antarctic silverfish data used in this study. The data sources were screened to avoid duplicate reporting of biomass data sets

\begin{tabular}{|c|c|c|c|}
\hline & Life history stage & Units & Reference \\
\hline January-February 1988 & Postlarvae & ind. $\left(100 \mathrm{~m}^{3}\right)^{-1}$ & Guglielmo et al. (1997) \\
\hline November 1989 - January 1990 & Postlarvae & ind. $\left(100 \mathrm{~m}^{3}\right)^{-1}$ & Granata et al. (2000) \\
\hline November-December 1994 & Postlarvae \& juvenile & ind. $\left(100 \mathrm{~m}^{3}\right)^{-1}$ & $\begin{array}{l}\text { Vacchi et al. (1999), } \\
\text { Granata et al. (2000) }\end{array}$ \\
\hline January-February 1996 & Juvenile & ind. $\left(100 \mathrm{~m}^{3}\right)^{-1}$ & Granata et al. (2000) \\
\hline December 1997 & Larvae, postlarvae, \& juvenile & ind. $\left(1000 \mathrm{~m}^{3}\right)^{-1}$ & La Mesa et al. (2010) \\
\hline January-February 2000 & Larvae, postlarvae, \& juvenile & ind. $\left(1000 \mathrm{~m}^{3}\right)^{-1}$ & La Mesa et al. (2010) \\
\hline January 2004 & Larvae, postlarvae, \& juvenile & ind. $\left(1000 \mathrm{~m}^{3}\right)^{-1}$ & La Mesa et al. (2010) \\
\hline
\end{tabular}

Table 3. Summary of environmental data, source, data time range, and references used in this study. Environmental distributions were produced from the summer average data (December-February). SeaWiFS: Sea-viewing Wide-Field-of-view Sensor, SSM/I: Special Sensor Microwave Imager. The percent sea ice cover was calculated from the SSM/I measurements using the methodology given in Cavalieri et al. (1996)

\begin{tabular}{|llcll}
\hline Environmental variable & Source & Time & Reference \\
\hline $\begin{array}{l}\text { Maximum temperature } \\
\text { below 300 }\left(^{\circ} \mathrm{C}\right)\end{array}$ & Ross Sea Circulation Model & December 2010 - March 2011 & Mack et al. (2017) \\
$\begin{array}{l}\text { Chlorophyll }\left(\mathrm{mg} \mathrm{m}^{-3}\right) \\
\text { Mixed layer depth }(\mathrm{m})\end{array}$ & Ocean Color SeaWiFS & Ross Sea Circulation Model & September 2010 - February 2012 & Mack et al. (2017) \\
$\begin{array}{l}\text { Sea ice (\% coverage) } \\
\text { Surface speed }\left(\mathrm{m} \mathrm{s}^{-1}\right)\end{array}$ & SSM/I & Ross Sea Circulation Model & September 2010 - February 2012 & Cavalieri et al. (1996) \\
\end{tabular}

the surface by $>0.01 \mathrm{~kg} \mathrm{~m}^{-3}$, was calculated from the simulated daily averaged temperature and salinity values, and averaged to provide monthly means. The monthly MLD values were then averaged to obtain a summer seasonal MLD climatology (Fig. 2C).

The summer average sea ice concentration (Table 3) distribution in the Ross Sea was obtained from Special Sensor Microwave Imager (SSM/I) measurements made between 1988 and 2003 as part of an analysis of sea ice changes in the Ross Sea (Fig. 3A, Smith et al. 2014b).

Estimates of the magnitude and variability of the east-west and north-south components of the velocity field are provided by simulated surface speed distributions that were obtained from the Ross Sea circulation model (Table 3, Mack et al. 2017). The simulated daily surface speeds were averaged to obtain monthly (December-February) distributions, which were then averaged to provide a summer distribution (Fig. 3B).

\section{Construction of species distributions and environmental data sets}

The krill, Antarctic silverfish, and environmental data sets were imported into the geographic informa- tion system package ArcGIS 10.2.2 to construct distributions of the individual variables and to overlay combinations of variables (e.g. bathymetry and krill). The distance from each krill and silverfish measurement to the location of the coastline and ice shelf front, defined by the $0-\mathrm{m}$ isobath, and shelf break, defined by the 700-m isobath, was measured using the ArcGIS function 'Near.' These variables were included as part of the environmental variable data set. Values of the environmental variables that correspond to the location of each krill and Antarctic silverfish measurement were extracted using the ArcGIS function 'Extract Multi Values to Points.'

\section{Statistical analyses}

The optimized hot spot analysis in the spatial statistics extension of ArcGIS was used to identify statistically significant spatial clustering of high values (hot spots) and low values (cold spots) in the krill, Antarctic silverfish, and environmental distributions using the Getis-Ord Gi* statistic (Getis \& Ord 1992). The significance of the $\mathrm{Gi}^{*}$ statistic for each data value provides an associated $z$-score, p-value, and confidence level bin. The $\mathrm{Gi}^{*}$ value for each data point is then partitioned into a bin that reflects its signifi- 

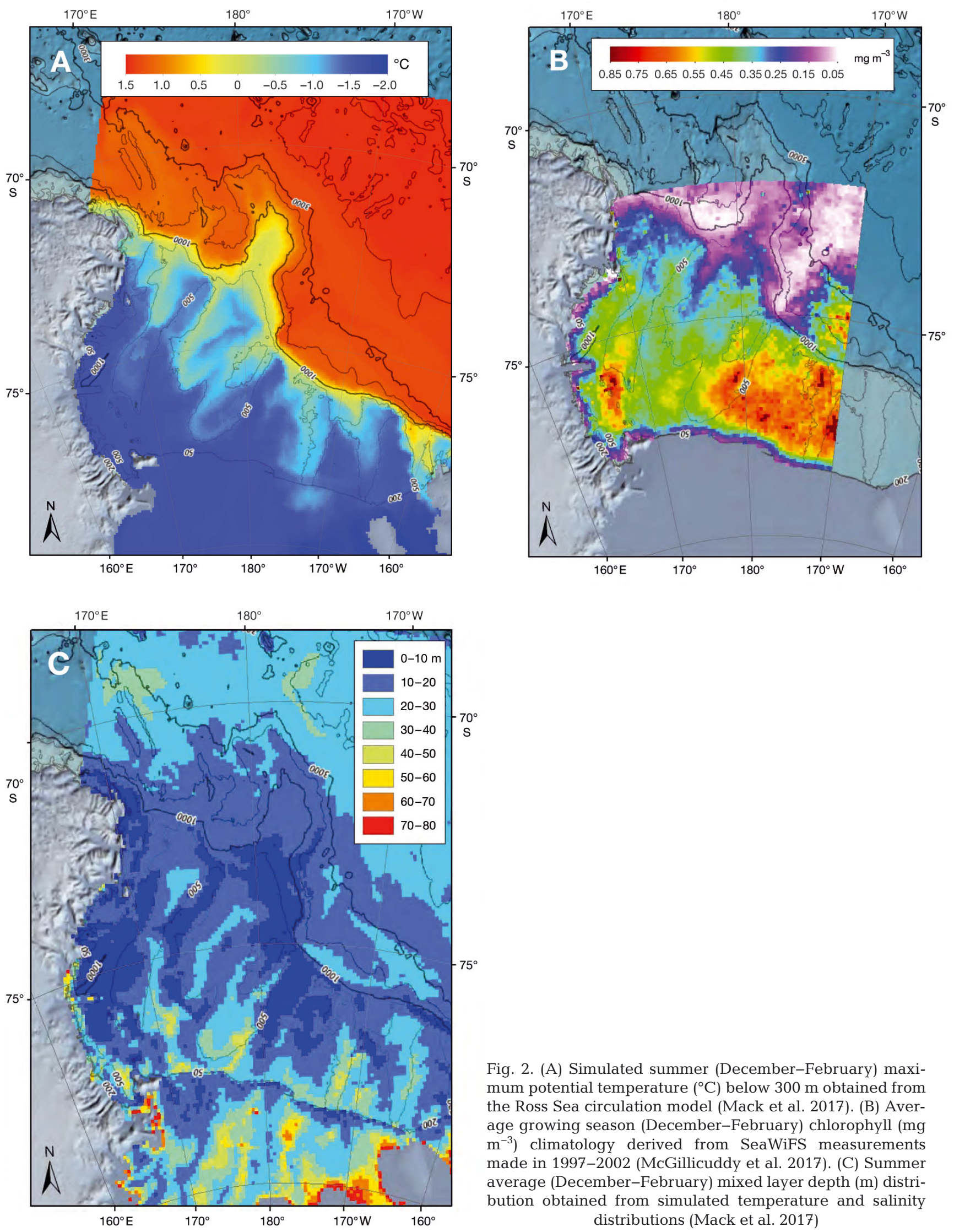

Fig. 2. (A) Simulated summer (December-February) maximum potential temperature $\left({ }^{\circ} \mathrm{C}\right)$ below $300 \mathrm{~m}$ obtained from the Ross Sea circulation model (Mack et al. 2017). (B) Average growing season (December-February) chlorophyll (mg $\mathrm{m}^{-3}$ ) climatology derived from SeaWiFS measurements made in 1997-2002 (McGillicuddy et al. 2017). (C) Summer average (December-February) mixed layer depth (m) distribution obtained from simulated temperature and salinity distributions (Mack et al. 2017) 

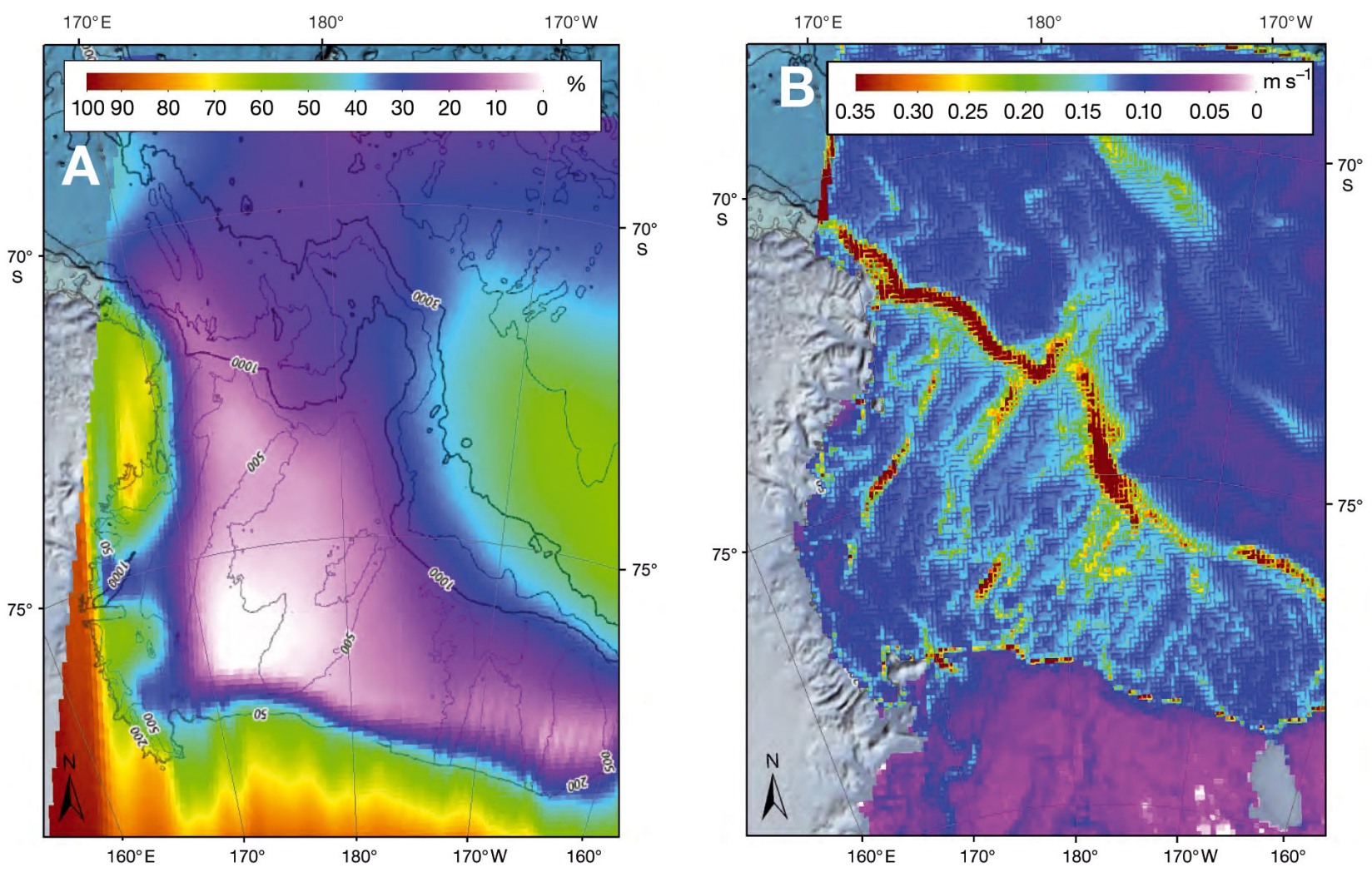

Fig. 3. Summer (December-February) averaged (A) SSM/I-derived distribution of sea ice concentration (0-100\% coverage) obtained from measurements made between 1988 and 2003 (Cavalieri et al. 1996), and (B) surface speed ( $\mathrm{m} \mathrm{s}^{-1}$ ) obtained from the simulated circulation distributions (Mack et al. 2017)

cance level, i.e. confidence intervals of $99 \%\left( \pm 3 \mathrm{Gi}^{*}\right.$ value), $95 \%$ ( $\pm 2 \mathrm{Gi}^{*}$ value), and $90 \%$ ( $\pm 1 \mathrm{Gi}^{*}$ value). The remaining $\mathrm{Gi}^{*}$ values are considered to be statistically insignificant.

Histograms that partitioned the number of krill and Antarctic silverfish measurements into $0.25^{\circ} \mathrm{C}$ temperature and 100-m bathymetry bins were used to identify initial relationships in the data sets. The numerous 0 values in the data sets for the 3 species (i.e. absence of the species) biased the histogram frequencies and obscured underlying patterns. Therefore, histograms were constructed that excluded 0 values to better highlight relationships with temperature and bathymetry.

The spatial autocorrelation (Moran's I) function from the spatial statistics extension of ArcGIS was used to measure the similarity of features. The Moran's I statistic uses the data locations and values to estimate the degree of similarity in the data and the type of similarity, i.e. clustered, dispersed, or random. A positive Moran's I index indicates that high values cluster near high values and low values cluster near low values, signifying spatially clustered distributions, and a negative Moran's I index indicates no clustering of the data (high values are near low values). Very high or low $z$-scores associated with significant $\mathrm{p}$-values reflect a non-random pattern in the data. The spatial autocorrelation analysis was done for each species and each environmental variable using the entire data set (western Ross Sea scale) and using the portion of the data set identified by the $99 \%$ confidence interval in the hot spot analysis (hot spot scale) (Tables S1 \& S2 in the Supplement at www.int-res.com/articles/suppl/m584p045_ supp.pdf).

A traditional empirical orthogonal function (EOF) analysis separates time series measurements at a series of locations into sets of related spatial patterns with certain time histories (Preisendorfer \& Mobley 1988). The EOF implementation used in this study analyzes a set of variables, i.e. the species and environmental distributions, at a series of locations. The EOF yields patterns of related variables, given by the eigenfunction, and locations at which the patterns are dominant, the loading vector. The eigenvalue for each mode indicates the fraction of the variance of the data set represented by a given mode. Significant modes are identified by those with eigenvalues that 
are greater than the mean of all the eigenvalues, i.e. 'the average eigenvalue test' (Preisendorfer \& Mobley 1988). The eigenfunctions indicate which variables are related for a given mode, and the loading vector indicates the dominance of a pattern. The eigenvector provides the direction of change (positive or negative) relative to the mean. The EOF analysis was done for the species and environmental data in the region defined by the chlorophyll distribution (Fig. 2B), which sets a common area for all data sets. The analysis was done using the entire data set (western Ross Sea scale) and the data set defined by the $99 \%$ confidence interval obtained for the biological hot spot (hot spot scale). The mean value was subtracted from each data set to remove the effects of trends so that the data variability is better represented. The resultant data set was divided by the standard deviation of the data to create a 0 mean unit variance data set. This detrended and scaled data set was used in the EOF analysis.

\section{RESULTS}

\section{Distributions}

Antarctic krill are found over most of the western Ross Sea continental shelf, along the shelf break, and in offshelf waters (Fig. 4A). The inner shelf region is characterized by low biomass $\left(<1 \mathrm{t} \mathrm{km}^{-2}\right)$ or absence of Antarctic krill (Fig. 4A). The exception is the southwest inner shelf, where Antarctic krill biomass was consistently $1-10 \mathrm{t} \mathrm{km}^{-2}$. The shallow areas over Mawson and Pennell Banks have the largest biomass of $100-1000 \mathrm{t} \mathrm{km}^{-2}$. Antarctic krill biomass is consistently 100-1000 $\mathrm{t} \mathrm{km}^{-2}$ along the shelf break/slope region and in the northwestern corner of the Ross Sea (Fig. 4A). Biomass values in excess of $1000 \mathrm{t} \mathrm{km}^{-2}$ occur in the northwest Ross Sea off the coast of Cape Adare (Fig. 4A).

Crystal krill occur at low biomass levels (less than $1 \mathrm{t}$ $\mathrm{km}^{-2}$ ) over most of the western Ross Sea continental shelf and were not found in samples from the eastern part of the study region (Fig. 4B). Localized areas of biomass of 1-10 t km${ }^{-2}$ occur over Mawson and Pennell Banks, the southern inner shelf near the Ross Ice Shelf, and the southwestern inner shelf (Fig. 4B). Biomass of $100-1000 \mathrm{t} \mathrm{km}^{-2}$, the highest observed, occurs in and around Terra Nova Bay in the far western Ross Sea.

The early life stages of Antarctic silverfish occur at low $\left(<10\right.$ ind. $\left.\left[1000 \mathrm{~m}^{3}\right]^{-1}\right)$ abundance levels over most of the western continental shelf and are absent in offshelf waters (Fig. 4C). Localized regions of enhanced abundance occur on the shelf in the shallower waters over Mawson and Pennell Banks. The largest and most consistent occurrence of Antarctic silverfish is in Terra Nova Bay (Fig. 4C), where abundance values exceed 10000 ind. $\left(1000 \mathrm{~m}^{3}\right)^{-1}$. Just outside of Terra Nova Bay, along the southwestern flank of Mawson Bank, Antarctic silverfish abundance levels are similar to those in Terra Nova Bay (Fig. 4C).

The histograms show that the largest number of Antarctic krill observations are associated with temperatures of 1 to $1.25^{\circ} \mathrm{C}$ and bottom depths of $1000 \mathrm{~m}$ (Fig. 5A). The Antarctic krill histogram shows secondary peaks at colder temperatures $\left(-1.25\right.$ to $\left.-1.5^{\circ} \mathrm{C}\right)$ and shallower bottom depths (300 and $400 \mathrm{~m}$ ). The largest number of crystal krill observations are associated with temperatures of -1.75 to $-2^{\circ} \mathrm{C}$ and bottom depths between 500 and $800 \mathrm{~m}$ (Fig. 5B). Secondary peaks in the crystal krill histogram are at -1.0 to $-1.5^{\circ} \mathrm{C}$ and 300,400 , and $500 \mathrm{~m}$. The temperatures and bottom depths that correspond to the largest number of observations of the early life stages of Antarctic silverfish are similar to those associated with crystal krill, -1.75 to $-2^{\circ} \mathrm{C}$ and 500 and $700 \mathrm{~m}$ (Fig. 5C). The fewest observations occur at warm temperatures and $900 \mathrm{~m}$.

\section{Hot spot and spatial autocorrelation analysis}

The optimized hot spot analysis shows that the Antarctic krill distribution over most of the Ross Sea continental shelf is not significantly different from an average distribution (Fig. 6A). The exception is the northwestern shelf/slope region. The area defined by the $99 \%$ confidence level (red circles) outlines a biological hot spot (region enhanced relative to surrounding areas) for Antarctic krill along and off the shelf/slope region to the east of Cape Adare (Fig. 6A). The $90 \%$ confidence level expands this region to the north and southward onto the outer continental shelf (Fig. 6A). The crystal krill distribution is relatively uniform over most of the continental shelf, except in Terra Nova Bay (Fig. 6B), where a distinct hot spot occurs. The region outlined by the $99 \%$ confidence level includes the inner and northern shelf region of Terra Nova Bay and the outer part of the Drygalski Ice Tongue. The region encompassed by the $90 \%$ confidence interval slightly expands the hot spot area (Fig. 6B). The biological hot spot of the early life stages of Antarctic silverfish is also concentrated in Terra Nova Bay and in the near environs with a distribution that is similar to crystal krill (Fig. 6C). 

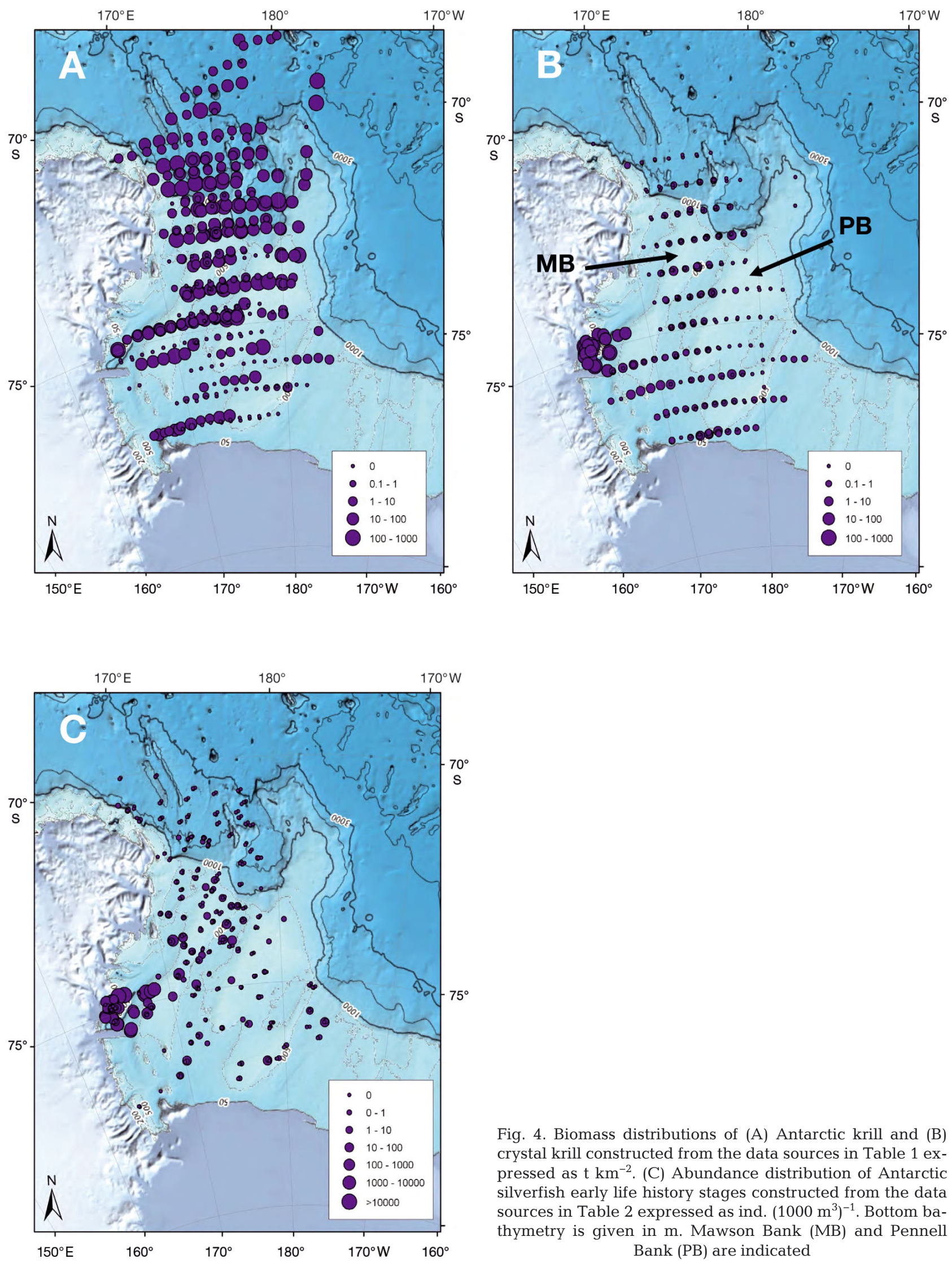

Fig. 4. Biomass distributions of (A) Antarctic krill and (B) crystal krill constructed from the data sources in Table 1 expressed as $\mathrm{t} \mathrm{km}^{-2}$. (C) Abundance distribution of Antarctic silverfish early life history stages constructed from the data sources in Table 2 expressed as ind. $\left(1000 \mathrm{~m}^{3}\right)^{-1}$. Bottom bathymetry is given in m. Mawson Bank (MB) and Pennell Bank (PB) are indicated 

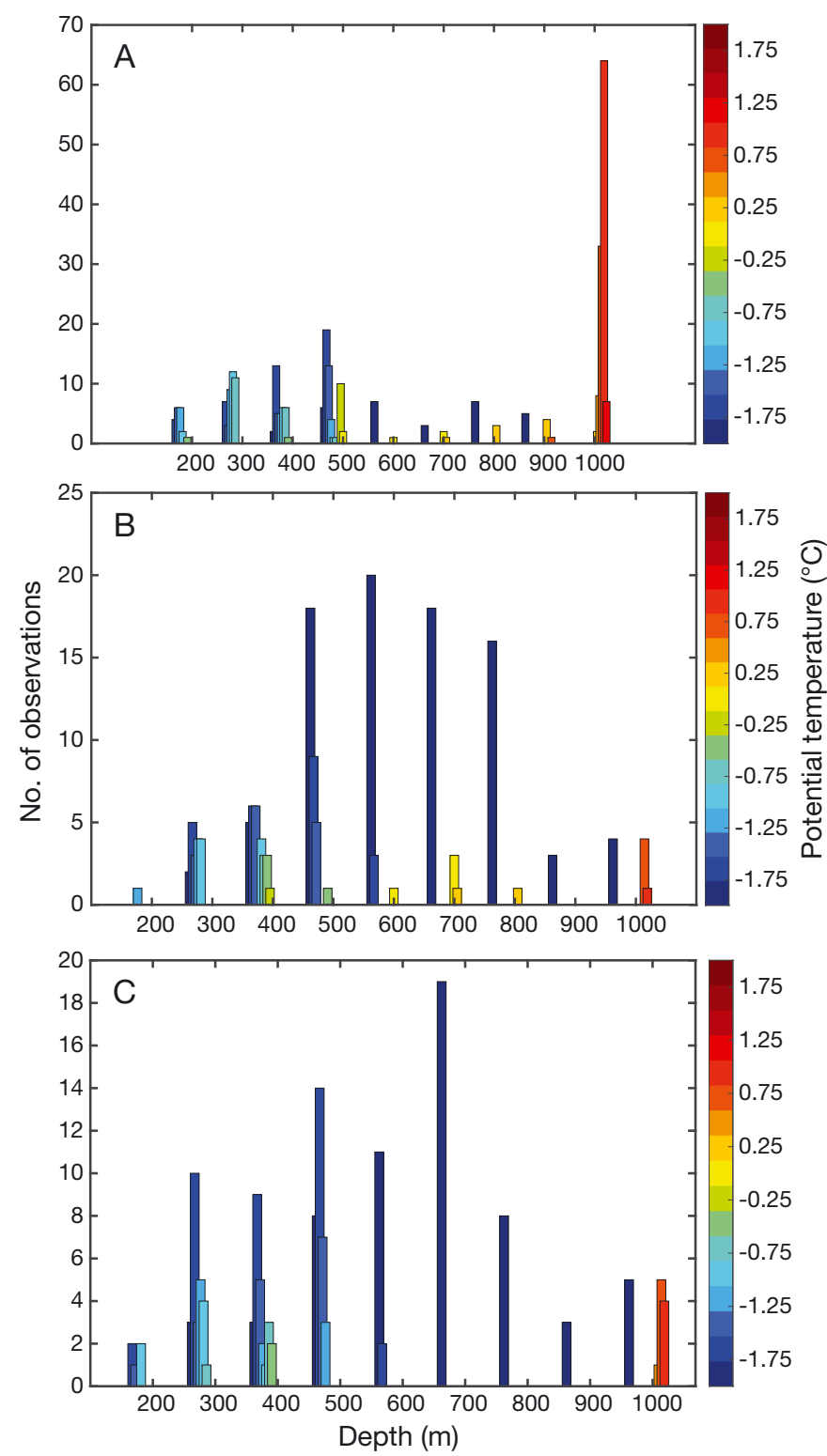

Fig. 5. Frequency distribution of (A) Antarctic krill, (B) crystal krill, and (C) Antarctic silverfish observations (excluding 0 values) as a function of potential temperature $\left({ }^{\circ} \mathrm{C}\right)$ and bottom depth (m). Chi-squared goodness-of-fit tests indicate that the 3 histograms differ from a normal distribution, with $\mathrm{p}$-values of $<0.0005,0.0022$, and $<0.0005$, respectively

The spatial autocorrelation analysis indicates that the distribution pattern of Antarctic krill is statistically random at the western Ross Sea scale (z-score $=$ 0.7597, $\mathrm{p}=0.4474$, Table S1 in the Supplement). In contrast, the distributions of adult crystal krill and early life stages of Antarctic silverfish are clustered at a statistically significant level at the western Ross Sea scale $(p<0.01$, Table S1). The environmental variables associated with the krill and Antarctic sil- verfish values are clustered at a statistically significant level ( $\mathrm{p}<0.01$, Table S1).

At the hot spot scale, the Antarctic and crystal krill biomass distributions are statistically random $(z-$ score $=-0.1272, \mathrm{p}=0.8988$ and $z$-score $=-0.6648, \mathrm{p}=$ 0.5062 , respectively, Table S2). The Antarctic silverfish abundance distribution is statistically clustered at the hot spot scale, as are the associated environmental variables $(z$-score $>2.58, \mathrm{p}<0.01$, Table S2).

\section{EOF analysis}

Western Ross Sea scale

The eigenvalues obtained from the EOF analysis (Table S3) show that the first 4 modes are significant for Antarctic krill and crystal krill and the first 3 modes are significant for the Antarctic silverfish (Fig. 7) at the western Ross Sea scale (Table 4).

The first mode obtained for the Antarctic krill western Ross Sea scale data set (Fig. 8A, blue bars) explains $38.04 \%$ of the variance (Table S3) and is accounted for by the association of southerly (northerly) latitudes, cold (warm) water temperature, higher (lower) chlorophyll concentrations, and increased (decreased) distance to the shelf break (Table 4). Mode 2 (Fig. 8A, cyan bars) explains $16.78 \%$ of the variability in the data set (Table S3), and the eigenvectors indicate that this is attributed to bottom depth, sea ice, and surface speed. Mode 2 is associated with higher concentrations of sea ice, slower surface speeds, and deeper bottom depths (Table 4). Modes 3 and 4 (Fig. 8A, yellow and red bars) account for $11.86 \%$ and $10.49 \%$ (Table S3) of the variance, respectively, and suggest a correspondence between longitude and MLD for Mode 3, and longitude, surface speed, and distance to the coast for Mode 4 (Table 4).

The 4 significant modes obtained for the crystal krill data set at the western Ross Sea Scale explain $36.31,17.53,10.6$, and $9.21 \%$ of the variance (Table S3), respectively. Mode 1 is associated with latitude, distance to the shelf break, distance to the coast, and temperature (Fig. 8B, blue bars), suggesting correspondences between northerly (southerly) latitudes, increased (decreased) distance from the coast, decreased (increased) distance to the shelf break, and warmer (colder) temperatures (Table 4). The variance in Mode 2 is attributed to bottom depth, chlorophyll, and sea ice (Fig. 8B, cyan bars), suggesting an association among shallow bottom depths, decreased concentrations of sea ice, and higher concentrations 

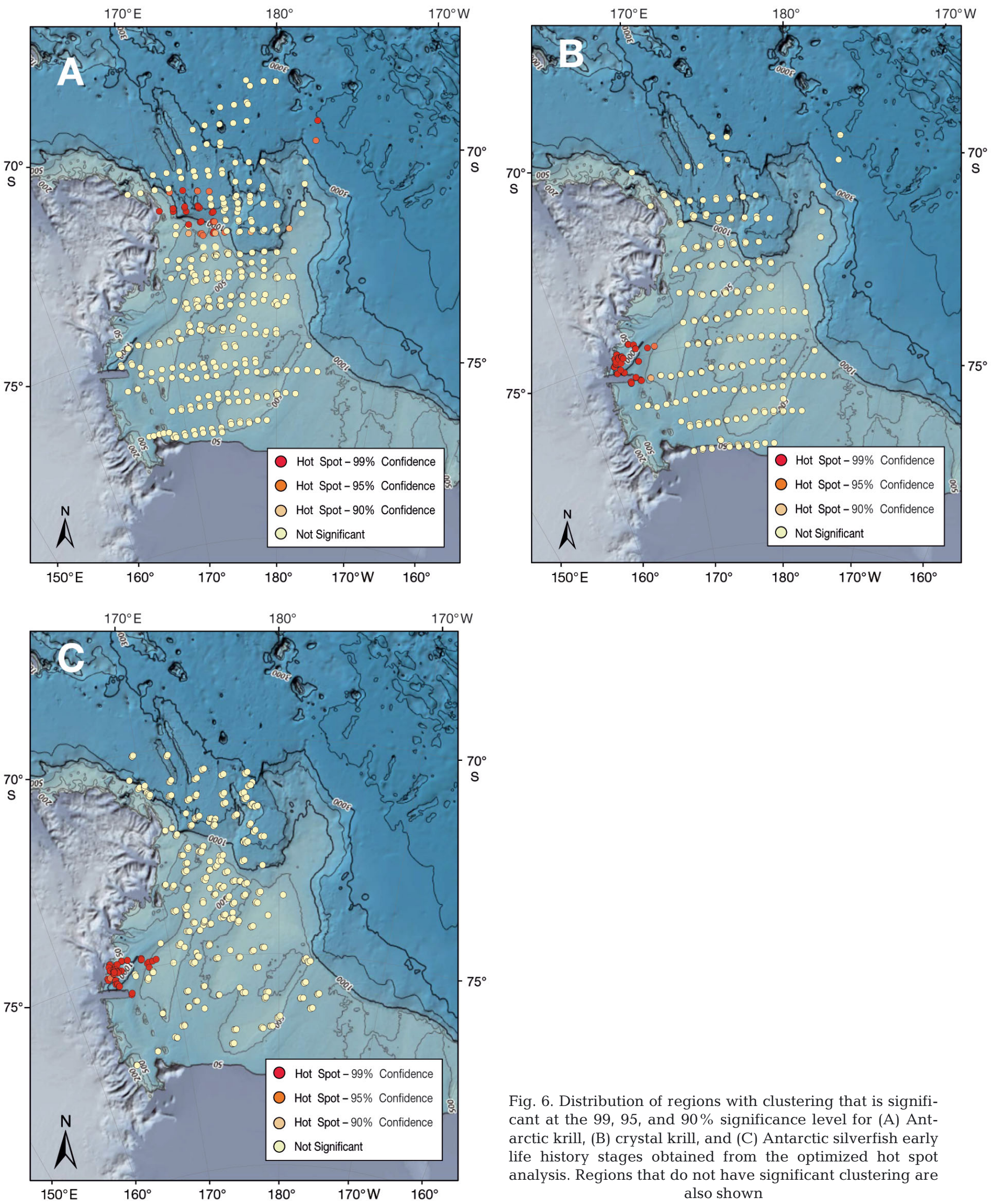

Fig. 6. Distribution of regions with clustering that is significant at the 99, 95, and 90\% significance level for (A) Antarctic krill, (B) crystal krill, and (C) Antarctic silverfish early life history stages obtained from the optimized hot spot analysis. Regions that do not have significant clustering are also shown 


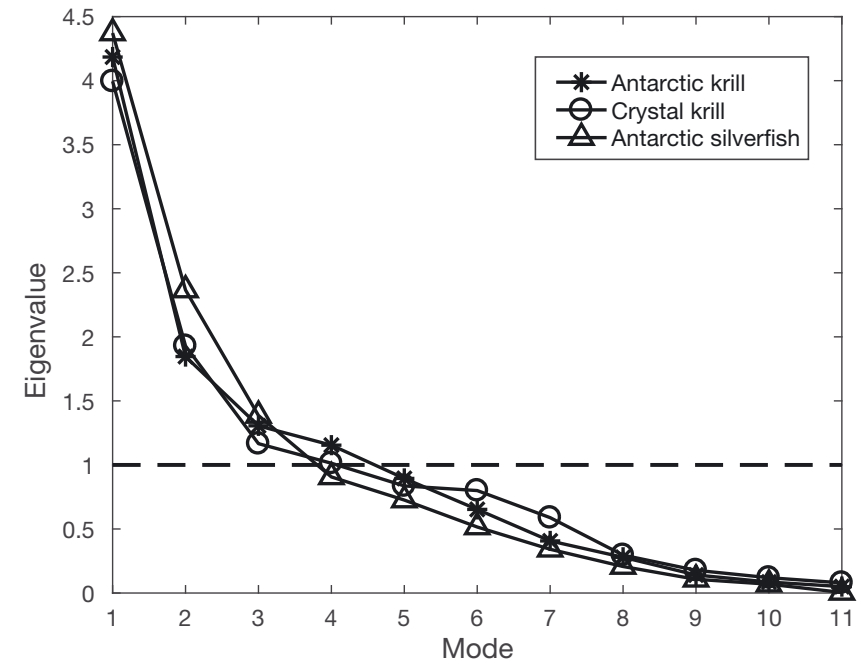

Fig. 7. Eigenvalues and associated modes for Antarctic krill, crystal krill, and Antarctic silverfish obtained from the entire data set (western Ross Sea scale). Modes with eigenvalues greater than the mean $(=1$, dashed line) are significant

of chlorophyll. Modes 3 and 4 indicate correspondences between longitude and MLD (Fig. 8B, yellow bars), and crystal krill biomass, bottom depth, and MLD (Fig. 8B, red bars), respectively (Table 4). Mode 4 indicates that decreased (increased) crystal krill biomass is associated with increased (decreased) bottom depths and deeper (shallower) mixed layers (Table 4).

The 3 significant modes obtained for Antarctic silverfish explain $39.74,21.5$, and $12.59 \%$ of the variance in the data set (Table S3), respectively. Mode 1 is associated with eastern longitudes, distance to the shelf break, distance to the coast, and temperature (Fig. 8C, blue bars), suggesting that eastern (western) longitudes are associated with warmer (colder) temperatures, decreased (increased) distance from the shelf break, and increased (decreased) distance to the coast (Table 4). The variance in Mode 2 is accounted for by bottom depth, sea ice, and chlorophyll concentration (Table 4), suggesting an association among deeper bottom depths, increased sea ice coverage, and decreased chlorophyll concentrations (Fig. 8C, cyan bars). Mode 3 provides an association among bottom depth, surface speed, and MLD (Table 4), in which slower surface speeds are associated with deeper bottom depths and deeper mixed layers (Fig. 8C, yellow bars).

\section{Hot spot scale}

The eigenvalues obtained from the EOF analysis for each species and associated environmental distributions at their associated hot spot scale (Table S4) show that the first 4 modes are significant for Antarctic krill and Antarctic silverfish, and the first 3 modes are significant for crystal krill (Fig. 9).

The 4 significant modes for the Antarctic krill data set at their associated hot spot explain 43.93, 23.3, 12.86 , and $10 \%$ of the variance (Table S4), respectively. Mode 1 characterizes their northwestern corner hot spot with bottom depth and water temperature (Fig. 10A, blue bars). Mode 2 further refines their

Table 4. Summary of the dominant variables and direction of change (positive: +, negative: - ) relative to the mean for each species at the western Ross Sea scale and the hot spot scale obtained from the EOF analysis. Long: longitude, Lat: latitude, Bio: biomass, Abu: abundance, Depth: bottom depth, Speed: surface speed, Temp: temperature below $300 \mathrm{~m}$, Coast: distance to coastline, Ice: sea ice coverage, Chla: chlorophyll a concentration, Shelf: distance to shelf break, MLD: mixed layer depth

\begin{tabular}{|c|c|c|c|c|}
\hline & \multicolumn{2}{|c|}{$\longrightarrow$ Western Ross Sea scale -} & \multicolumn{2}{|c|}{$\longrightarrow$ Hot spot scale } \\
\hline & Significant mode & Dominant variables & Significant mode & Dominant variables \\
\hline \multirow{4}{*}{$\begin{array}{l}\text { Antarctic } \\
\text { krill }\end{array}$} & 1 & Lat (-), Temp (-), Chla (+), Shelf $(+)$ & 1 & Depth (+), Temp (+) \\
\hline & 2 & Depth $(+)$, Speed $(-)$, Ice $(+)$ & 2 & Ice $(-)$, Shelf $(-)$ \\
\hline & 3 & Long (-), Ice (+), MLD (-) & 3 & Lat $(+)$, Speed $(+)$ \\
\hline & 4 & Long (-), Speed (-), Coast (+) & 4 & $\operatorname{Bio}(-), \operatorname{MLD}(-)$ \\
\hline \multirow[t]{4}{*}{$\begin{array}{l}\text { Crystal } \\
\text { krill }\end{array}$} & 1 & $\begin{array}{l}\text { Lat }(+), \text { Temp }(+), \text { Coast }(+), \\
\text { Shelf }(-)\end{array}$ & 1 & $\begin{array}{l}\text { Long }(-) \text {, Temp }(-) \text {, Coast }(-) \text {, } \\
\text { Chla }(-) \text {, Shelf }(+)\end{array}$ \\
\hline & 2 & Depth (-), Ice (-), Chla (+) & 2 & Lat (-), Depth (+), MLD (-) \\
\hline & 3 & Long (-), MLD (-) & 3 & Lat $(+)$, Bio $(+)$, Temp $(-)$ \\
\hline & 4 & Bio (-), Depth (+), MLD (+) & & \\
\hline \multirow[t]{4}{*}{$\begin{array}{l}\text { Antarctic } \\
\text { silverfish }\end{array}$} & 1 & $\begin{array}{l}\text { Long }(+), \text { Temp }(+), \text { Coast }(+), \\
\text { Shelf }(-)\end{array}$ & 1 & $\begin{array}{l}\text { Long }(-) \text {, Speed }(-) \text {, } \\
\text { Temp (-), Coast }(-)\end{array}$ \\
\hline & 2 & Depth (+), Ice (+), Chla (-) & 2 & Depth (-), Ice (+), MLD (+) \\
\hline & 3 & Depth $(+)$, Speed $(-)$, MLD (+) & 3 & Lat $(-)$ \\
\hline & & & 4 & Abu (+), Chla (-) \\
\hline
\end{tabular}



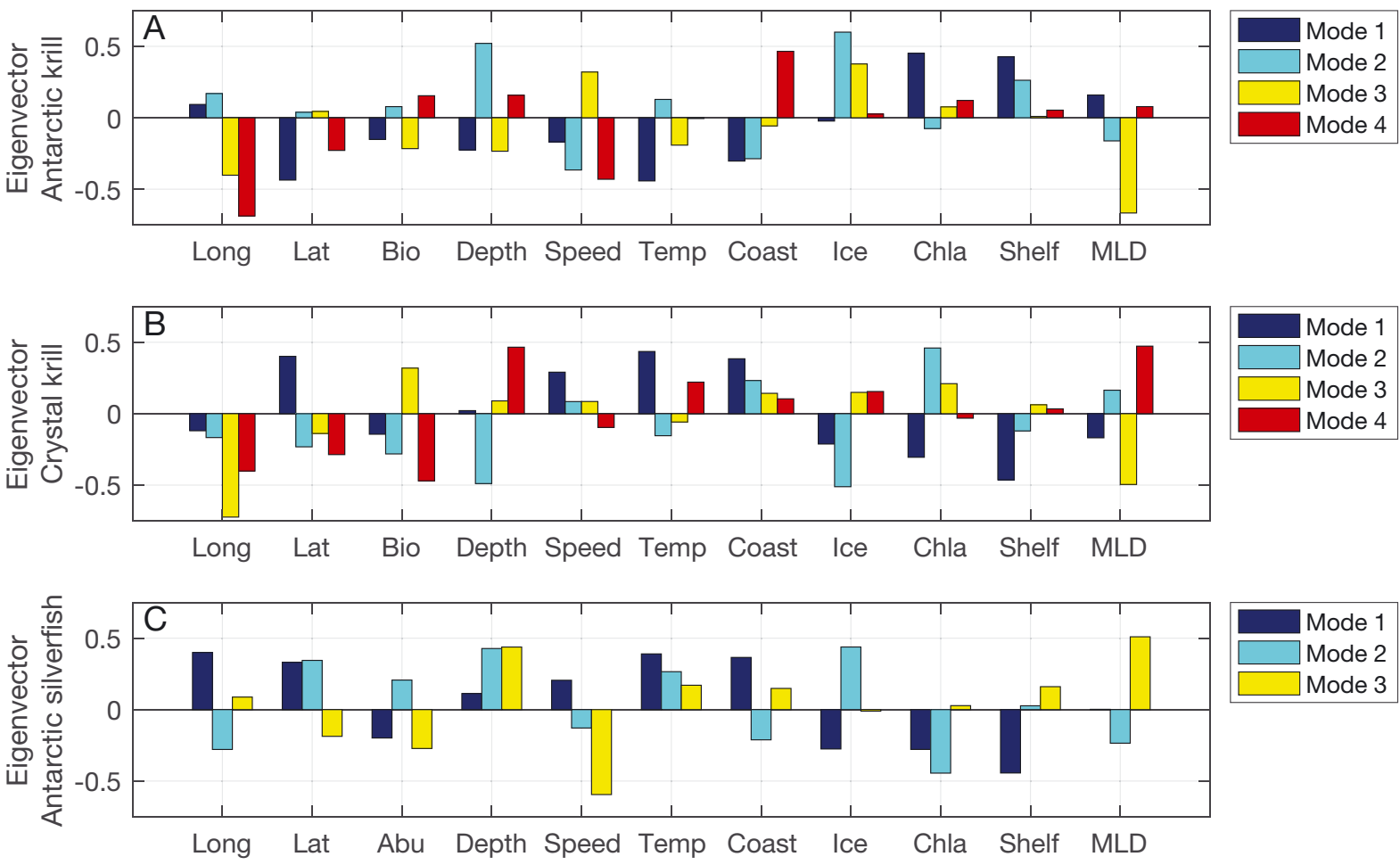

Environmental variables

Fig. 8. Eigenvectors showing partitioning of variance for each significant EOF mode and environmental variable obtained from the entire data set (western Ross Sea scale) for (A) Antarctic krill, (B) crystal krill, and (C) Antarctic silverfish. Long: longitude, Lat: latitude, Bio: biomass, Abu: abundance, Depth: bottom depth, Speed: surface speed, Temp: temperature below $300 \mathrm{~m}$, Coast: distance to coastline, Ice: sea ice coverage, Chla: chlorophyll a concentration, Shelf: distance to shelf break, MLD: mixed layer depth

habitat by including sea ice cover and distance to the shelf break (Fig. 10A, cyan bars). The eigenvectors for mode 3 indicate an association between surface speed and latitude (Fig. 10A, yellow bars), and a correspondence between Antarctic krill biomass and MLD is given by Mode 4 (Fig. 10A, red bars). The first 3 modes suggest that the hot spot habitat for Antarctic krill in the northwestern corner of the Ross Sea shelf break region is defined by deep bottom depths with warm water temperatures, decreased sea ice, and fast surface speeds (Table 4). Mode 4 of the EOF suggests that within this habitat, increased Antarctic krill biomass is associated with waters that have deeper mixed layers (Table 4).

The 3 significant modes at the hot spot scale for crystal krill explain $39.79,17.86$, and $15.02 \%$ of the variance in the data set, respectively (Table S4). The eigenvectors for Mode 1 capture the Terra Nova Bay characteristics between longitude, distance to the coast, temperature, and chlorophyll concentration (Fig. 10B, blue bars). Mode 2 further refines the habitat characteristics by including bottom depth,

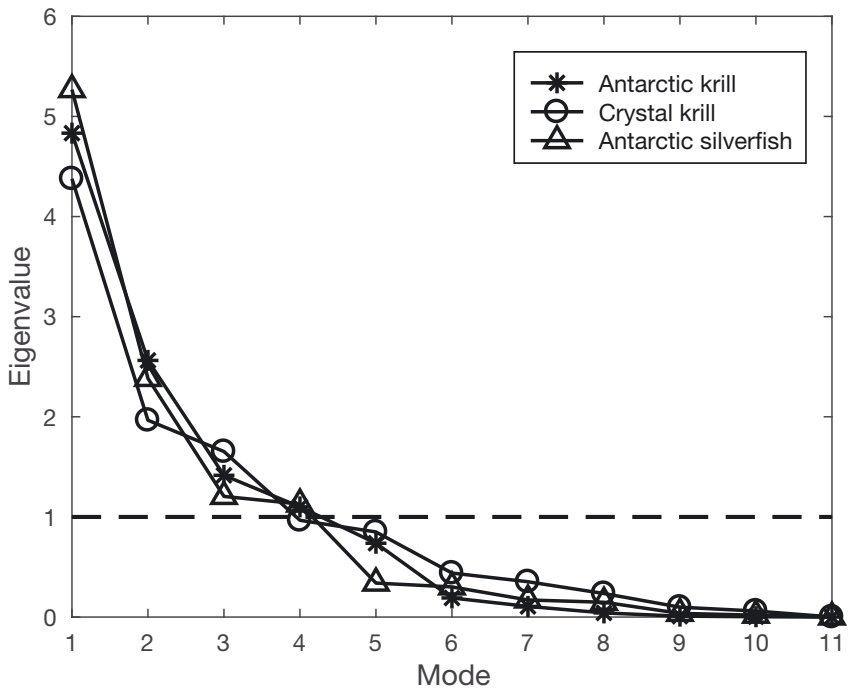

Fig. 9. Eigenvalues and associated modes for Antarctic krill, crystal krill, and Antarctic silverfish obtained from the data set defined by the $99 \%$ confidence interval from the hot spot analysis (hot spot scale). Modes with eigenvalues greater than the mean $(=1$, dashed line) are significant 

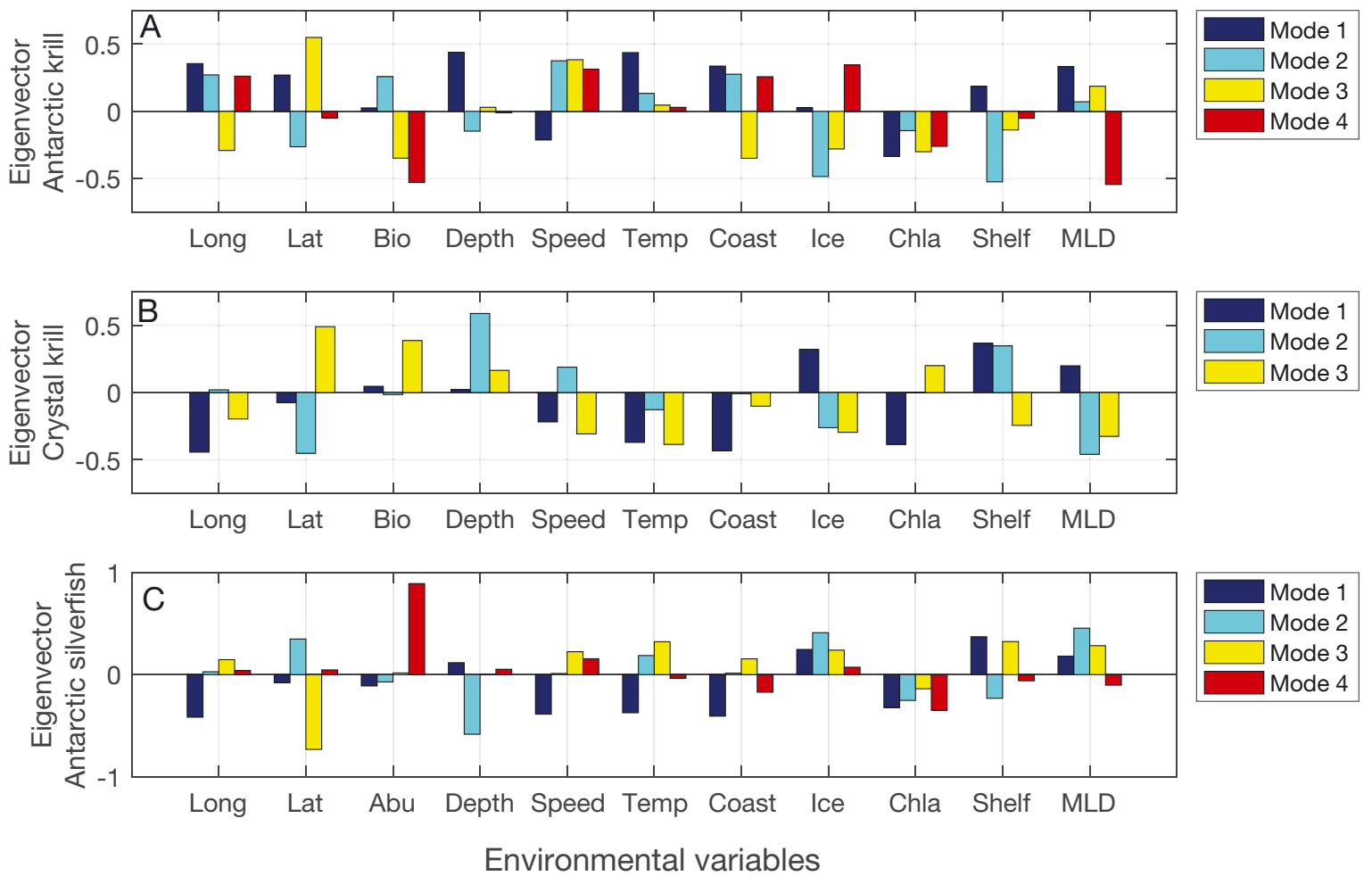

Fig. 10. Eigenvectors showing partitioning of variance for each significant EOF mode and environmental variable obtained from the data set defined by the $99 \%$ confidence level from the hot spot analysis (hot spot scale) for (A) Antarctic krill, (B) crystal krill, and (C) Antarctic silverfish. Environmental variables are abbreviated as in Fig. 8

latitude, and MLD (Fig. 10B, cyan bars). The eigenvectors for Mode 3 show an association among crystal krill biomass, water temperature, and latitude (Table 4). The first 2 modes suggest that the hot spot habitat in Terra Nova Bay for crystal krill is defined by westerly longitudes with cold temperatures, low chlorophyll concentrations, and deep bottom depths. Mode 3 of the EOF suggests that within Terra Nova Bay, increased crystal krill biomass is associated with the northern latitudes within this habitat and cold temperatures (Fig. 10B, yellow bars).

The 4 significant modes from the EOF analysis at the Terra Nova Bay hot spot scale for Antarctic silverfish explain $47.88,21.66,10.95$, and $10.26 \%$, respectively (Table S4). Mode 1 indicates an association between longitude, surface speed, temperature, and distance to the coast and shelf (Fig. 10C, blue bars). Modes 2 and 3 add bottom depth, MLD, ice, and latitude as additional habitat characteristics, respectively (Fig. 10C, cyan and yellow bars). Mode 4 provides a correspondence between Antarctic silverfish abundance and chlorophyll concentration (Fig. 10C, red bars). These in total suggest that the hot spot habitat for the early life stages of Antarctic silverfish in Terra Nova Bay is defined by southwesterly loca- tions with slow surface speeds, cold temperatures, shallow bottom depths, deep MLDs, and increased sea ice cover (Fig. 10C). Within the Terra Nova Bay habitat, increased abundance of the early life stages of Antarctic silverfish is associated with low chlorophyll concentrations (Table 4).

\section{DISCUSSION}

\section{Perspective}

The relationships developed to describe correspondences between terrestrial and marine species and environmental conditions take many forms (see review by Elith \& Leathwick 2009), but all have the goal of providing quantitative and robust models that allow the prediction of potential effects of changing environmental conditions on species distributions. For the Antarctic marine system, species distribution models have focused on Antarctic krill and top predators because of their importance in the food web, and the availability of observations to describe the distributions and habitat characteristics (Ichii 1990, Trathan et al. 2003, Naganobu et al. 2006, Atkinson 
et al. 2008, Murase et al. 2013). Early attempts to explain the observed circumpolar distribution of Antarctic krill were based on qualitative comparisons with environmental conditions, such as temperature, sea ice, and bathymetry (Marr 1962, Mackintosh 1973). While providing insights into basic factors affecting Antarctic krill distributions, these qualitative studies lacked the ability to quantify relationships with environmental distributions, and to assess regional differences in controls. More recent studies have developed statistical relationships and models that allow quantification of the relative effects of environmental conditions on circumpolar (Hofmann \& Hüsrevoğlu 2003, Atkinson et al. 2004, 2008) and regional distributions of Antarctic krill (Weber \& ElSayed 1985, Witek et al. 1988, Trathan et al. 2003, Lawson et al. 2008). These studies identified patterns and provided correlations between Antarctic krill and environmental variables, but also showed that these exhibited considerable variability, which is in part attributed to different space and time scales that are resolved by the observations used in the analyses. Similar studies for other krill species, such as crystal krill, have not been done, except through qualitative analyses that relate presence to ambient conditions (e.g. Fevolden 1980, Brinton \& Townsend 1991, Daly \& Zimmerman 2004). The general distribution of the early life history stages of Antarctic silverfish is known (see review by La Mesa \& Eastman 2012), but again correspondences with environmental conditions are based on qualitative analyses (Hubold 1984, Kellermann 1986a,b, Koubbi et al. 2011).

Our analysis advances these studies by quantitatively characterizing the habitats of 3 important midtrophic level species in the Ross Sea. The use of environmental distributions obtained from a highresolution circulation model provides a range of environmental distributions at the scale of the Ross Sea that are not possible to obtain from observations. The addition of satellite-derived distributions provides a comprehensive characterization of the environmental conditions, that when combined with ship-based biomass distributions, provide a basis for quantitative assessments of distributional patterns and habitats of each species.

Observations of the 3 species included in this analysis come from cruises made in the austral spring and summer; observations from other times of the year are lacking due to the logistical constraints of making ship-based measurements in the Ross Sea. These observations capture general characteristics of summer conditions, but are not sufficiently dense in space or time to capture variability. As a result, the primary relationships that emerge from this analysis are those that characterize the physical environment of the Ross Sea. Observations from all seasons taken with space and time resolution that reveals variability are needed to define the full range of the habitats occupied by the 3 species.

The general characteristics of the distributions of the 3 species show clear and distinct patterns in the Ross Sea. Each species occupies a localized habitat that is defined by different environmental characteristics (Table 5). The data sources to estimate the krill biomass and Antarctic silverfish abundance used in the EOF analysis are based on acoustic measurements and net tows (e.g. oblique tows), respectively, which integrate over the upper 120 to $160 \mathrm{~m}$. Thus, the habitat characteristics are representative of the upper water column rather than specific depths where the krill and Antarctic silverfish were collected.

Antarctic krill occupy the habitat along the outer continental shelf break. Crystal krill and the early life stages of Antarctic silverfish occupy similar and overlapping habitats in the Terra Nova Bay region that are distinct from the Antarctic krill habitat. Separation of Antarctic krill and crystal krill habitats in the western Ross Sea has been described for specific times and locations (Sala et al. 2002, Taki et al. 2008, Leonori et al. 2017), but this study shows that the separation is a general characteristic of the 2 species.

Interactions between crystal krill and Antarctic silverfish in the Terra Nova Bay habitat are not seen from the EOF analysis, but biological interactions such as predator-prey responses are not captured in the data used in this analysis. Some overlap in the distribution of the 3 species occurs over the continental shelf, but the regions where the biomass is enhanced (i.e. statistically significant) relative to average conditions, i.e. the hot spots for the 2 krill species, are separate and distinct.

\section{Habitat characteristics}

\section{Antarctic krill}

Although Antarctic krill are distributed throughout the Ross Sea, the habitat defined by this analysis indicates that this species is found in areas overlying warm water at depth with decreased sea ice concentrations and proximity to the shelf break (Table 5), i.e. conditions that are found off and along the northwestern shelf/slope region. Many studies have shown that Antarctic krill are associated with the shelf/slope region throughout the Antarctic (Hosie 1991, Miquel 


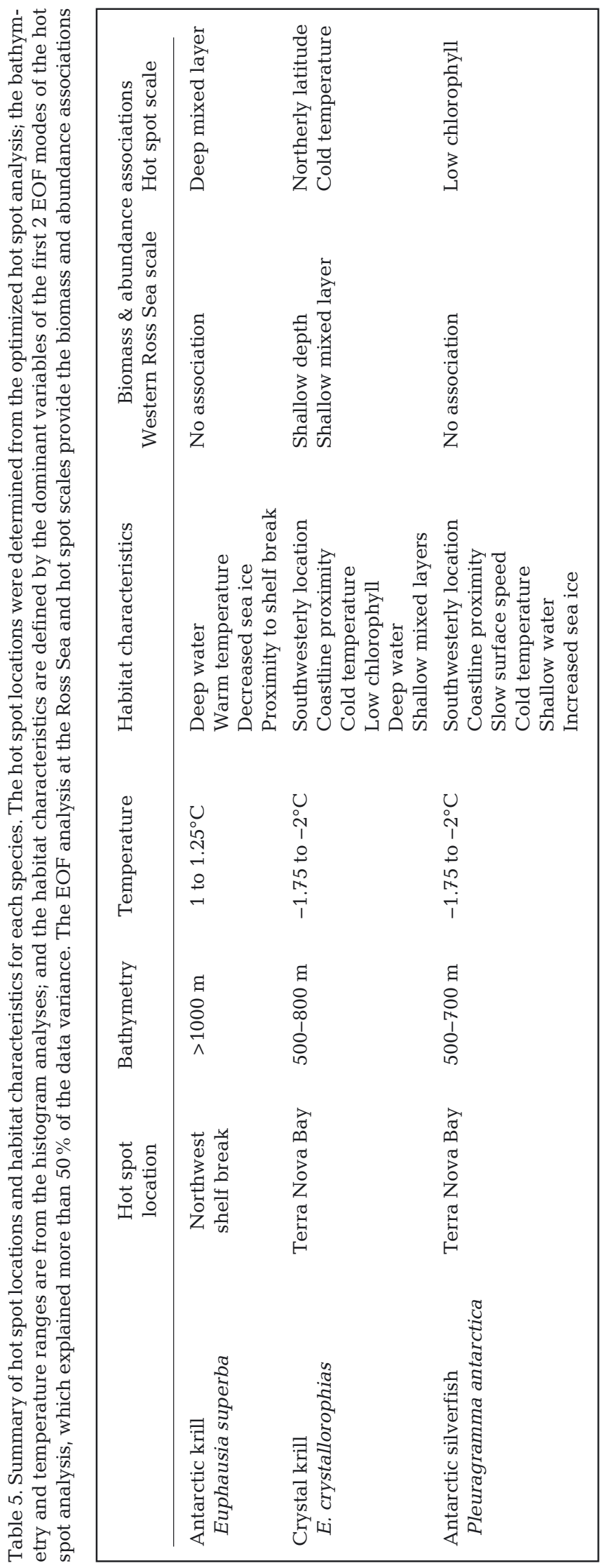

1991, Trathan et al. 2003, Ashjian et al. 2004, Siegel 2005, Azzali et al. 2006, Taki et al. 2008) and note that this area is important to many parts of their life history (Nicol 2006). Moreover, the circumpolar analysis by Atkinson et al. (2008) found that $87 \%$ of the Antarctic krill population occurs over deep water and speculated that this habitat protects against intense predation pressure found in shallower shelf regions, where the species is accessible to a range of predators.

The Antarctic krill hot spot region in the northwestern Ross Sea is associated with shelf/slope waters of $>1000 \mathrm{~m}$ and temperatures of 1 to $1.25^{\circ} \mathrm{C}$ (Table 5). This hot spot overlies an area where intrusions of CDW occur along the outer shelf region (Dinniman et al. 2003, Smith et al. 2007, Orsi \& Wiederwohl 2009), which is considered necessary for successful completion of the first phase of their early life history (Ross et al. 1988, Hofmann et al. 1992, Hofmann \& Hüsrevoğlu 2003). The northwestern Ross Sea is a spawning region for Antarctic krill (Spiridonov 1996) further supporting identification of this area as a habitat.

The slower surface speeds associated with the habitat in the northwestern corner of the Ross Sea provide a mechanism for maintaining this region as a hot spot. Simulated circulation distributions (Dinniman et al. 2003) show alternating regions of onoffshelf flow along the northwestern shelf with about a $20-25 \mathrm{~km}$ scale that are associated with a closed gyre circulation. Numerical Lagrangian simulations implemented for the western Ross Sea in which particles were released along the shelf/ slope and over the continental shelf show on-offshelf transport along the shelf/slope region (Piñones et al. 2016). Particle transport was to the northwest along the outer shelf with retention in the shelf/ slope region that corresponds to the Antarctic krill hot spot. Estimates of Antarctic krill life history stage, based on particle transport times, showed that the aggregated particles corresponded to larval and adult stages (Piñones et al. 2016).

The Antarctic krill distribution in the hot spot region is statistically random. This suggests that the distribution at this scale is variable and unpredictable, similar to results from studies in other Antarctic regions (Priddle et al. 1988, Sushin \& Shulgovsky 1999, Trathan et al. 2003, Lawson et al. 2008). Krill are not only structured by environmental conditions (such as currents), but also by behavioral and ecological pressures, such as the acquisition of food and avoidance of predators, which affect variability and regional distributions (Daly \& 
Macaulay 1991); these factors were not included in this analysis. The EOF analysis also indicated that enhanced Antarctic krill biomass is associated with deeper mixed layers, which may be related to food supply, although no correspondence with surface chlorophyll emerged from the analysis.

\section{Crystal krill}

Crystal krill are typically found in inshore neritic environments throughout the Antarctic (Fevolden 1980, O'Brien 1987, Thomas \& Green 1988, Hosie 1991, Nordhausen 1994, Pakhomov \& Perissinotto 1996, Sala et al. 2002, Daly \& Zimmerman 2004, Amakasu et al. 2011). In the Ross Sea, crystal krill are widely distributed over the western continental shelf and are concentrated in Terra Nova Bay. The general habitat characteristics for crystal krill determined from this study consist of southwesterly locations near the coast with cold temperatures $\left(1.75\right.$ to $\left.-2^{\circ} \mathrm{C}\right)$, low chlorophyll, bottom depths between 500 and $800 \mathrm{~m}$, and shallow mixed layers (Table 5). These conditions define a primary habitat in Terra Nova Bay, which supports a statistically significant region of enhanced crystal krill biomass.

The crystal krill distribution at the western Ross Sea scale is clustered at a statistically significant level, whereas the distribution in Terra Nova Bay is statistically random. This suggests that gradients in environmental variables are structuring the crystal krill at larger scales, but their distributions at smaller scales are responding to ecological and behavioral controls. The EOF analysis at the western Ross Sea scale showed that increased crystal krill biomass is associated with shallow bathymetry and shallow mixed layers, i.e. conditions that are associated with the shallow banks that extend across the continental shelf (Smith et al. 2014b). The EOF analysis indicated that increased crystal krill biomass is associated with colder water temperatures and northerly latitudes in Terra Nova Bay, which is consistent with observations that showed highest crystal krill biomass in the northerly region of Terra Nova Bay (Guglielmo et al. 2009).

The inverse relationship with chlorophyll that emerged from the EOF analysis as a habitat characteristic for crystal krill is counter to the positive relationship found by Leonori et al. (2017). The satellitederived chlorophyll climatology used for the EOF analysis shows values in Terra Nova Bay that are generally $<0.5 \mathrm{mg} \mathrm{m}^{-3}$ and does not resolve variability at mesoscale or sub-mesoscale scales, which are likely the scales that crystal krill target. A more complete description of habitat characteristics is provided by including in situ chlorophyll measurements that are coincident with crystal krill distributions (e.g. Leonori et al. 2017), which resolve relevant scales.

Although speed did not emerge as a primary habitat characteristic at either scale, results from numerical Lagrangian simulations show particle retention in Terra Nova Bay and over the shallow banks in the western Ross Sea (Piñones et al. 2016). The crystal krill biomass data set used in the EOF analysis had too few observations $(<1 \%$ of total data) from over the shallow banks to support the suggestion that these are retention areas for crystal krill. In Terra Nova Bay, the sampling distribution for crystal krill covered primarily the continental shelf (Guglielmo et al. 2009), which is an area of uniform slow speeds in the simulated circulation distribution. As a result, a relationship with speed cannot be determined because the biomass values are associated with the same speed values. Enhanced spatial resolution in the sampling of crystal krill distributions in Terra Nova Bay and over the shallow banks is needed to resolve and better define habitat relationships for this region.

\section{Antarctic silverfish}

Antarctic silverfish are typically found over continental shelf waters throughout the Antarctic (Hubold 1984, DeWitt et al. 1990, White \& Piatkowski 1993, Trunov 2001, Donnelly \& Torres 2008) and exhibit a circum-Antarctic distribution (Emslie \& McDaniel 2002). This species has a wide distribution throughout the Ross Sea continental shelf (DeWitt 1970, Granata et al. 2000, Ackley et al. 2003, Donnelly et al. 2004, O'Driscoll et al. 2011), but occurs in higher abundance in particular regions. The habitat defined by this analysis indicates that the early life history stages of this species are found in southwesterly locations with cold temperatures $\left(-1.75\right.$ to $\left.-2^{\circ} \mathrm{C}\right)$, bottom depths of 500 and $700 \mathrm{~m}$, slow surface speeds, increased sea ice concentration, deep mixed layers, and proximity to the coast (Table 5). Other features are also important factors for the early life history of silverfish, including proximity to an ice shelf or glacial tongue, canyons, water mass stratification, polynyas, and katabatic winds (review in Vacchi et al. 2012b), all of which are features associated with Terra Nova Bay. The Antarctic silverfish distributions are clustered at a statistically significant level at the western Ross Sea and Terra Nova Bay scales, suggesting similar environmental structuring of their distributions. 
The highest abundance of Antarctic silverfish early life stages occurs in Terra Nova Bay, which was identified as a statistically significant hot spot and is known as a nursey area for silverfish eggs and larvae (Vacchi et al. 2012a). Antarctic silverfish tend to spawn in ice-covered coastal regions, ice shelf areas, and polynyas (Vacchi et al. 2004, 2012a), and use sea ice as a nursery for their eggs and early life stages (Kellermann 1986a,b, Daneri \& Carlini 2002). Antarctic silverfish spawn in the lower water column, and embryos, which are slightly positively buoyant, are found associated with sea-ice thickness and platelet ice (Vacchi et al. 2004, 2012a,b). The slow surface speeds that emerged as a characteristic for the Antarctic silverfish habitat will facilitate retention of the early life stages in the productive polynya region. Unlike the crystal krill, the distribution of Antarctic silverfish observations (La Mesa et al. 2010) was sufficient to capture speed as a habitat characteristic, which highlights the importance of designing sampling strategies to include scales of environmental controls.

The EOF analysis indicated that sea ice was not a strong factor structuring the Terra Nova Bay habitat, which is counterintuitive for a species that depends on sea ice for reproduction and food supply. This result is likely an artifact of the ship-based sampling, which avoids regions with high sea ice coverage. For the Terra Nova Bay hot spot, the EOF analysis indicated that increased Antarctic silverfish abundance is associated with low chlorophyll concentrations, which is also counterintuitive given the high levels of primary production in Terra Nova Bay (Arrigo et al. 1998a). As for crystal krill, the satellite-derived chlorophyll climatology did not resolve variability at scales that are relevant to Antarctic silverfish.

\section{Climate considerations}

The habitat characterizations obtained from this study provide a basis for understanding potential changes in the distribution of the 3 species as climate affects environmental conditions in the Ross Sea. Projections of conditions for 2050 and 2100 that are based on assumed warming trends and changes in wind forcing suggest that the Ross Sea will experience decreased summer sea ice concentration and extent, earlier formation of polynyas, expansion of the Ross Sea polynya, shallower summer MLDs, and a decrease in the advection of CDW onto the shelf (Smith et al. 2014 b). The 3 species of interest to this study are successful at present, but they are stenothermal (able to tolerate only a small range of temperatures) and have life cycles that are dependent on sea ice, making them potentially sensitive to climatic change.

Summer seasonal sea ice coverage is projected to decrease to $44 \%$ of current coverage, and that for 2100 is projected to decrease further to $22 \%$ of current conditions (Smith et al. 2014b). Habitat observations show that crystal krill and Antarctic silverfish occupy ice-covered regions. Reduction of this habitat may impact both species through effects on food supply, adult reproduction, and availability of nursery grounds for early life history stages. Both species have life history strategies that are timed with the opening of polynyas, and earlier polynya formation may result in a mismatch with their required environmental conditions, producing decreased reproductive success and survival. Reduced sea ice may favor early spawning by Antarctic krill and increase recruitment (Siegel \& Loeb 1995) due to the extended growth period throughout the summer months. However, this species also depends on sea ice as an overwintering habitat that provides food sources and protection for early life history stages (Daly 1990, 2004) as well as older stages (Siegel \& Loeb 1995).

Projected decreases in CDW inputs to the Ross Sea continental shelf and shallower MLDs will potentially reduce nutrient supply to the upper water column and allow the ocean to remain stratified for a longer period of time (Smith et al. 2014b). Projections for 2050 suggest that these changes will reduce the relative contribution of Phaeocystis antarcticum to the continental shelf production and favor diatom production (Smith et al. 2014a,b, Kaufman et al. 2017). This may provide increased food supply for all 3 species, especially Antarctic krill, which prefer diatoms as food (Haberman et al. 2003). However, reduced CDW may adversely affect the ability of Antarctic krill to complete the descent-ascent portion of their early life history, which depends on warm water at depth to accelerate embryo and early larval stage development.

The projected changes in environmental conditions may also alter the present distribution of hot spots, which are foci for locally intense energy fluxes within the food web (Atkinson et al. 2001, Murphy et al. 2007). Changes in environmental conditions that alter hot spot location, size, and persistence potentially affect the distribution, abundance, and relative availability of the 3 mid-trophic level species, that in turn, affect all trophic levels of the Ross Sea food web. Ainley et al. $(2006,2015)$ showed that reduced availability of the 2 krill species in late austral summer resulted in a trophic cascade that caused diet switching, changes 
in foraging behavior, and reduced abundance of top predators. The hot spot locations identified in this study are in areas associated with land-based colonies of penguins (Woehler 1993, Ainley et al. 2010, Smith et al. 2014a) and enhanced abundance of seals and cetaceans (Stirling 1969, see review by Smith et al. 2007). Hence, alterations to these sites have potentially large consequences for the Ross Sea food web.

\section{CONCLUSIONS}

The continental shelf break/slope region of the Ross Sea provides a productive habitat with features that favor Antarctic krill. Similarly, the inner shelf region within Terra Nova Bay provides a habitat that supports crystal krill and the early life stages of Antarctic silverfish. The localization of energy transfer in these regions provides a defined area for quantifying energy flows in the food web. This localization also makes the food web productivity vulnerable to environmental changes.

This study takes a bottom-up approach to defining habitat characteristics that are based on the assumption that the distributions of the 3 mid-trophic level species are controlled by environmental conditions. However, predation pressure and predator foraging strategies are important top-down controlling factors that need to be combined with environmental controls to account for variability in prey distributions. Prey behavior such as vertical migrations and swarm formations are also biological and behavioral components that may play a role in structuring the distributions of the 3 mid-trophic level species (Taki et al. 2008, Wiebe et al. 2011). The distribution of early life stages is likely controlled by bottom up factors such as circulation and temperature (e.g. Hofmann \& Hüsrevoğlu 2003, Piñones \& Federov 2016, Murphy et al. 2017), but older life stages are more likely controlled by growth potential and predation (Atkinson et al. 2008). Refinement of the habitats identified in this study requires inclusion of the effects of predation, as well as behavioral and species interactions, such as competition, both within and between trophic levels.

The habitats for the 3 mid-trophic level species identify areas of the Ross Sea that deserve focused management. Environmental changes in these regions coupled with possible pressures from resource use, such as fishing, could alter the balance in the food web and overall production of the Ross Sea. The results from this study provide further rationale and support for ecosystem-level conservation that underlie the selection of the Ross Sea marine protected areas.
Acknowledgements. This study was supported by the National Science Foundation, Office of Polar Programs Grants ANT-0944174 and ANT-0838911, and Old Dominion University teaching and research assistantships to L.B.D., and A.P. thanks CONICYT for support through the Program FONDAP, Project 15150003. Thoughtful comments provided by Peter Sedwick, Mark Butler, and Ari Friedlaender improved an earlier version of this manuscript. Statistical advice from Chester Grosch, data contributions from Dennis McGillicuddy, and Ross Sea circulation simulations from Stefanie Mack are graciously appreciated. We thank Marino Vacchi for providing unpublished CCAMLR documents describing some of the Italian Antarctic cruises. A special thanks to Ari Friedlaender for the guidance and enthusiasm throughout this research. L.B.D. thanks Julie Morgan for the introduction to CCPO. This research was the basis for L.B.D.'s MSc thesis.

\section{LITERATURE CITED}

Ackley SF, Bengston JL, Boveng P, Castellini M and others (2003) A top-down, multidisciplinary study of the structure and function of the pack-ice ecosystem in the eastern Ross Sea, Antarctica. Polar Rec 39:219-230

Ainley DG, Ballard G, Dugger KM (2006) Competition among penguins and cetaceans reveals trophic cascades in the western Ross Sea, Antarctica. Ecology 87:2080-2093

Ainley DG, Russell JL, Jenouvrier S, Woehler EJ, Lyver PO, Fraser WR, Kooyman GL (2010) Antarctic penguin response to habitat change as Earth's troposphere reaches $2^{\circ} \mathrm{C}$ above preindustrial levels. Ecol Monogr 80: 49-66

Ainley DG, Ballard G, Jones RM, Jongsomjit D, Pierce SD, Smith WO Jr, Veloz S (2015) Trophic cascades in the western Ross Sea, Antarctica: revisited. Mar Ecol Prog Ser 534:1-16

Amakasu K, Ono A, Hirano D, Moteki M, Ishimaru T (2011) Distribution and density of Antarctic krill (Euphausia superba) and ice krill (E. crystallorophias) off Adélie Land in austral summer 2008 estimated by acoustical methods. Polar Sci 5:187-194

Arrigo KR, Weiss AM, Smith WO Jr (1998a) Physical forcing of phytoplankton dynamics in the southwestern Ross Sea. J Geophys Res 103:1007-1021

Arrigo KR, Worthen D, Schnell A, Lizotte MP (1998b) Primary production in Southern Ocean waters. J Geophys Res 103:15587-15600

Arrigo KR, Van Dijken GL, Bushinsky S (2008) Primary production in the Southern Ocean, 1997-2006. J Geophys Res 113:C08004

* Ashjian CJ, Rosenwaks GA, Wiebe PH, Davis CS and others (2004) Distribution of zooplankton on the continental shelf off Marguerite Bay, Antarctic Peninsula, during austral fall and winter, 2001. Deep Sea Res II 51:2073-2098

Atkinson A, Whitehouse MJ, Priddle J, Cripps GC, Ward P, Brandon MA (2001) South Georgia, Antarctica: a productive, cold water, pelagic ecosystem. Mar Ecol Prog Ser 216:279-308

Atkinson A, Siegel V, Pakhomov EA, Rothery P (2004) Longterm decline in krill stock and increase in salps within the Southern Ocean. Nature 432:100-103

Atkinson A, Siegel V, Pakhomov EA, Rothery P and others (2008) Oceanic circumpolar habitat of Antarctic krill. Mar Ecol Prog Ser 362:1-23 
Azzali M, Kalinowski J (2000) Spatial and temporal distribution of krill Euphausia superba biomass in the Ross Sea (1989-1990 and 1994). In: Faranda FM, Guglielmo L, Ianora A (eds) Ross Sea ecology. Springer-Verlag, Berlin, p 433-455

Azzali M, Leonori I, De Felice A, Russo A (2006) Spatial-temporal relationships between two euphausiid species in the Ross Sea. Chem Ecol 22:S219-S233

* Ballard G, Jongsomjit D, Veloz SD, Ainley DG (2012) Coexistence of the mesopredators in an intact polar ocean ecosystem: the basis for defining a Ross Sea marine protected area. Biol Conserv 156:72-82

Brinton E, Townsend AW (1991) Development rates and habitat shifts in the Antarctic neritic euphausiid Euphausia crystallorophias, 1986-87. Deep-Sea Res 38:1195-1211

Cavalieri D, Parkinson C, Gloersen P, Zwally HJ (1996) Sea ice concentrations from Nimbus-7 SMMR and DMSP SSM/I passive microwave data. National Snow and Ice Data Center, Boulder, CO. http://nsidc.org/data/nsidc0051.html

Daly KL (1990) Overwintering development, growth, and feeding of larval Euphausia superba in the Antarctic marginal ice zone. Limnol Oceanogr 35:1564-1576

Daly KL (2004) Overwintering growth and development of larval Euphausia superba: an interannual comparison under varying environmental conditions west of the Antarctic Peninsula. Deep Sea Res II 51:2139-2168

Daly KL, Macaulay MC (1988) Abundance and distribution of krill in the ice edge zone of the Weddell Sea, austral spring 1983. Deep-Sea Res 35:21-41

Daly KL, Macaulay MC (1991) Influence of physical and biological mesoscale dynamics on the seasonal distribution and behavior of Euphausia superba in the antarctic marginal ice zone. Mar Ecol Prog Ser 79:37-66

Daly KL, Zimmerman JJ (2004) Comparisons of morphology and neritic distributions of Euphausia crystallorophias and Euphausia superba furcilia during autumn and winter west of the Antarctic Peninsula. Polar Biol 28:72-81

Daneri GA, Carlini AR (2002) Fish prey of southern elephant seals, Mirounga leonine, at King George Island. Polar Biol 25:739-743

DeWitt HH (1970) The character of the midwater fish fauna of the Ross Sea, Antarctica. In: Holdgate MW (ed) Antarctic ecology, Vol 1. Academic Press, New York, NY, p 299-340

DeWitt HH, Heemstra PC, Gon O (1990) Nototheniidae. In: Gon O, Heemstra PC (eds) Fishes of the Southern Ocean. JLB Smith Institute of Ichthyology, Grahamstown, p 279-331

Dinniman MS, Klinck JM, Smith WO (2003) Cross-shelf exchange in a model of the Ross Sea circulation and biogeochemistry. Deep Sea Res II 50:3103-3120

Donnelly J, Torres JJ (2008) Pelagic fishes in Marguerite Bay region of the West Antarctic Peninsula shelf. Deep Sea Res II 55:523-539

Donnelly J, Torres JJ, Sutton TT, Simoniello C (2004) Fishes of the eastern Ross Sea, Antarctica. Polar Biol 27:637-650

Elith J, Leathwick JR (2009) Species distribution models: ecological explanation and prediction across space and time. Annu Rev Ecol Evol Syst 40:677-697

Emslie SD, McDaniel JD (2002) Adélie penguin diet and climate change during the middle to late Holocene in northern Marguerite Bay, Antarctic Peninsula. Polar Biol 25:222-229
Fevolden SE (1980) Krill off Bouvetöya and in the southern Weddell Sea with a description of larval stages of Euphausia crystallorophias. Sarsia 65:149-162

Getis A, Ord JK (1992) The analysis of spatial association by use of distance statistics. Geogr Anal 24:189-206

Granata A, Guglielmo L, Greco S, Vacchi M, Sidoti O, Zagami G, La Mesa M (2000) Spatial distribution and feeding habits of larval and juvenile Pleuragramma antarcticum in the western Ross Sea (Antarctica). In: Faranda FM, Guglielmo L, Ianora A (eds) Ross Sea ecology. Springer-Verlag, Berlin, p 369-393

* Guglielmo L, Granata A, Greco S (1997) Distribution and abundance of postlarval and juvenile Pleuragramma antarcticum (Pisces, Nototheniidae) off Terra Nova Bay (Ross Sea, Antarctica). Polar Biol 19:37-51

* Guglielmo L, Donato P, Zagami G, Granata A (2009) Spatiotemporal distribution and abundance of Euphausia crystallorophias in Terra Nova Bay (Ross Sea, Antarctica) during austral summer. Polar Biol 32:347-367

*Haberman KL, Ross RM, Quetin LB (2003) Diet of the Antarctic krill (Euphausia superba Dana): II. Selective grazing in mixed phytoplankton assemblages. J Exp Mar Biol Ecol 283:97-113

*Hofmann EE, Hüsrevoğlu YS (2003) A circumpolar modeling study of habitat control of Antarctic krill (Euphausia superba) reproductive success. Deep-Sea Res II 50: 3121-3142

* Hofmann EE, Capella JE, Ross RM, Quetin LB (1992) Models of early life history of Euphausia superba -Part 1. Time and temperature dependence during the descent-ascent cycle. Deep-Sea Res 39:1177-1200

Hosie GW (1991) Distribution and abundance of euphausiid larvae in the Prydz Bay region, Antarctica. Antarct Sci 3: $167-180$

Hosie GW (1994) The macrozooplankton communities in the Prydz Bay region, Antarctica. In: El-Sayed SZ (ed) Southern Ocean ecology: the BIOMASS perspective. Cambridge University Press, Cambridge, p 93-123

*Hubold G (1984) Spatial distribution of Pleuragramma antarcticum (Pisces: Nototheniidae) near the Filchner- and Larsen Ice Shelves (Weddell Sea/Antarctica). Polar Biol 3:231-236

Ichii T (1990) Distribution of Antarctic krill concentrations exploited by Japanese krill trawlers and minke whales. Proc NIPR Symp Polar Biol 3:36-56

KKaufman DE, Friedrichs MAM, Smith WO Jr, Hofmann EE, Dinniman MS, Hemmings JC (2017) Climate change impacts on southern Ross Sea phytoplankton composition, productivity, and export. J Geophys Res Oceans 122:2339-2359

Kellermann A (1986a) Geographical distribution and abundance of post larval and juvenile Pleuragramma antarcticum (Pisces, Notothenioidei) off the Antarctic Peninsula. Polar Biol 6:111-119

Kellermann A (1986b) On the biology of early life stages of notothenioid fishes (Pisces) off the Antarctic Peninsula. Ber Polarforsch 31:1-155

Koubbi P, O'Brien C, Loots C, Giraldo C and others (2011) Spatial distribution and inter-annual variations in the size frequency distribution and abundances of Pleuragramma antarcticum larvae in the Dumont d'Urville Sea from 2004 to 2010. Polar Sci 5:225-238

* La Mesa M, Eastman JT (2012) Antarctic silverfish: life strategies of a key species in the high-Antarctic ecosystem. Fish Fish 13:241-266 
La Mesa M, Catalano B, Russo A, Greco S, Vacchi M, Azzali $M(2010)$ Influence of environmental conditions of spatial distribution and abundance of early life stages of Antarctic silverfish, Pleuragramma antarcticum (Nototheniidae), in the Ross Sea. Antarct Sci 22:243-254

Laws RM (1985) The ecology of the Southern Ocean: the Antarctic ecosystem, based on krill, appears to be moving toward a new balance of species in its recovery from the inroads of whaling. Am Sci 73:26-40

Lawson GL, Wiebe PH, Ashjian CJ, Gallager SM, Davis CS, Warren JD (2004) Acoustically-inferred zooplankton distribution in relation to hydrography west of the Antarctic Peninsula. Deep-Sea Res II 51:2041-2072

Kawson GL, Wiebe PH, Ashjian CJ, Stanton K (2008) Euphausiid distribution along the Western Antarctic Peninsula - Part B: distribution of euphausiid aggregations and biomass, and associations with environmental features. Deep-Sea Res II 55:432-454

Leonori I, De Felice A, Canduci G, Costantini I, Biagiotti I, Giuliani G, Budillon G (2017) Krill distribution in relation to environmental parameters in mesoscale structures in the Ross Sea. J Mar Syst 166:159-171

Mack SL, Dinniman MS, McGillicuddy DJ Jr, Sedwick PN, Klinck JM (2017) Dissolved iron transport pathways in the Ross Sea: influence of tides and mesoscale eddies in a regional ocean model. J Mar Syst 166:73-86

Mackintosh NA (1973) Distribution of postlarval krill in the Antarctic. Discov Rep 36:95-156

Marr JWS (1962) The natural history and geography of the Antarctic krill (Euphausia superba Dana). Discov Rep 32: 33-464

McGillicuddy DJ Jr, Budillon G, Kustka A (2017) Mesoscale and high-frequency variability in the Ross Sea (Antarctica): an introduction to the special issue. J Mar Syst 166: $1-3$

Miller RG (1993) A history and atlas of the fishes of the Antarctic Ocean. Foresta Institute for Ocean and Mountain Studies, Carson City, NV

Miquel JC (1991) Distribution and abundance of post-larval krill (Euphausia superba Dana) near Prydz Bay in summer with reference to environmental conditions. Antarct Sci 3:279-292

Murase H, Kitakado T, Hakamada T, Matsuoka K, Nishiwaki S, Naganobu M (2013) Spatial distribution of Antarctic minke whales (Balaenoptera bonaerensis) in relation to spatial distributions of krill in the Ross Sea, Antarctica. Fish Oceanogr 22:154-173

Murphy EJ, Watkins JL, Trathan PN, Reid K and others (2007) Spatial and temporal operation of the Scotia Sea ecosystem: a review of large-scale links in a krillcentered food web. Philos Trans R Soc B 362:113-148

Murphy EJ, Thorpe SE, Tarling GA, Watkins JL, Fielding S, Underwood P (2017) Restricted regions of enhanced growth of Antarctic krill in the circumpolar Southern Ocean. Sci Rep 7:6963

Naganobu M, Nishiwaki S, Yasuma H, Matsukura R and others (2006) Interactions between oceanography, krill and baleen whales in the Ross Sea and adjacent waters: an overview of Kaiyo Maru-JARPA joint survey on 2004/05. J Cetacean Res Manag 10:438-439

Nicol S (2006) Krill, currents, and sea ice: Euphausia superba and its changing environment. Bioscience 56: 111-120

Nordhausen W (1994) Winter abundance and distribution of Euphausia superba, E. crystallorophias and Thysanoessa macrura in Gerlache Strait and Crystal Sound, Antarctica. Mar Ecol Prog Ser 109:131-142

* O'Brien DP (1987) Direct observations of the behavior of $E$. superba and E. crystallorophias (Crustacea: Euphausiacea) under pack ice during the Antarctic spring of 1985. J Crustac Biol 7:437-448

*'Driscoll RL, Macaulay GJ, Gauthier S, Pinkerton M, Hanchet S (2011) Distribution, abundance and acoustic properties of Antarctic silverfish (Pleuragramma antarcticum) in the Ross Sea. Deep-Sea Res II 58:181-195

Orsi AH, Wiederwohl CL (2009) A recount of Ross Sea waters. Deep-Sea Res II 56:778-795

*Pakhomov EA, Perissinotto R (1996) Antarctic neritic krill Euphausia crystallorophias: spatio-temporal distribution, growth and grazing rates. Deep-Sea Res I 43:59-87

Pakhomov EA, Perissinotto R (1997) Spawning success and grazing impact of Euphausia crystallorophias in the Antarctic shelf region. In: Battaglia B, Valencia J, Walton DWH (eds) Antarctic communities: species, structure and survival. Cambridge University Press, Cambridge, p 187-192

* Pinkerton MH, Bradford-Grieve JM (2014) Characterizing foodweb structure to identify potential ecosystem effects of fishing in the Ross Sea, Antarctica. ICES J Mar Sci 71: 1542-1553

Pinkerton MH, Bradford-Grieve JM, Hanchet SM (2010) A balanced model of the food web of the Ross Sea, Antarctica. CCAMLR Sci 17:1-31

Piñones A, Fedorov AV (2016) Projected changes of Antarctic krill habitat by the end of the $21^{\text {st }}$ century. Geophys Res Lett 43:8580-8589

`Piñones A, Hofmann EE, Dinniman MS, Davis LB (2016) Modeling the transport and fate of euphausiids in the Ross Sea. Polar Biol 39:177-187

Preisendorfer RM, Mobley CD (1988) Principal component analysis in meteorology and oceanography. Developments in Atmospheric Science, Vol 17. Elsevier, New York, NY

Priddle J, Croxall JP, Everson I, Heywood RB, Murphy EJ, Prince PA, Sear CB (1988) Large-scale fluctuations in distribution and abundance of krill-a discussion of possible causes. In: Sahrhage D (ed) Antarctic Ocean and resources variability. Springer, Berlin, p 169-182

Quetin LB, Ross RM (1984) School composition of the Antarctic krill Euphausia superba in the waters west of the Antarctic Peninsula in the austral summer of 1982. J Crustac Biol 4:96-106

Ross RM, Quetin LB, Kirsch E (1988) Effect of temperature on development times and survival of early larval stages of Euphausia superba Dana. J Exp Mar Biol Ecol 121: $55-71$

Sala A, Azzali M, Russo A (2002) Krill of the Ross Sea: distribution, abundance and demography of Euphausia superba and Euphausia crystallorophias during the Italian Antarctic Expedition (January-February 2000). Sci Mar 66:123-133

Siegel V (2005) Distribution and population dynamics of Euphausia superba: summary of recent findings. Polar Biol 29:1-22

* Siegel V, Loeb V (1995) Recruitment of Antarctic krill (Euphausia superba) and possible causes for its variability. Mar Ecol Prog Ser 123:45-56

Smith WO Jr, Ainley DG, Cattaneo-Vietti R (2007) Trophic interactions within the Ross Sea continental shelf ecosystem. Philos Trans R Soc Lond B Biol Sci 362:95-111 
Smith WO Jr, Sedwick PN, Arrigo KR, Ainley DG, Orsi AH (2012) The Ross Sea in a sea of change. Oceanography 25:90-103

Smith WO Jr, Ainley DG, Arrigo KR, Dinniman MS (2014a) The oceanography and ecology of the Ross Sea. Annu Rev Mar Sci 6:469-487

Smith WO Jr, Dinniman MS, Hofmann EE, Klinck JM (2014b) The effects of changing winds and temperatures on the oceanography of the Ross Sea in the $21^{\text {st }}$ century. Geophys Res Lett 41:1624-1631

Spiridonov VA (1996) A scenario of the Late-PleistoceneHolocene changes in the distributional range of Antarctic krill (Euphausia superba Dana). Polar Biol 15:161-174

Stirling I (1969) Distribution and abundance of the Weddell seal in the western Ross Sea, Antarctica. NZ J Mar Freshw Res 3:191-200

Sushin VA, Shulgovsky KE (1999) Krill distribution in the western Atlantic sector of the Southern Ocean during 1983/84, 1984/85 and 1987/88 based on the results of soviet meso-scale surveys conducted using an Isaacs-Kid Midwater trawl. CCAMLR Sci 6:59-70

Taki K, Yabuki T, Noiri Y, Hayashi T, Naganobu M (2008) Horizontal and vertical distribution and demography of euphausiids in the Ross Sea and its adjacent waters in 2004/2005. Polar Biol 31:1343-1356

Thomas PG, Green K (1988) Distribution of Euphausia crystallorophias within Prydz Bay and its importance to the inshore marine ecosystem. Polar Biol 8:327-331

Trathan PN, Brierley AS, Brandon MA, Bone D and others (2003) Oceanographic variability and changes in Antarctic krill (Euphausia superba) abundance at South Georgia. Fish Oceanogr 12:569-583

Trunov IA (2001) Occurrence of Pleuragramma antarcticum (Nototheniidae) off South Georgia Island and the South Sandwich Islands (Antarctica). J Ichthyol 41:549-550

Vacchi M, La Mesa M, Greco S (1999) Summer distribution and abundance of larval and juvenile fishes in the western Ross Sea. Antarct Sci 11:54-60

Vacchi M, La Mesa M, Dalù M, Macdonald J (2004) Early life stages in the life cycle of Antarctic silverfish, Pleura-

Editorial responsibility: Marsh Youngbluth,

Fort Pierce, Florida, USA gramma antarcticum in Terra Nova Bay, Ross Sea. Antarct Sci 16:299-305

*Vacchi M, DeVries AL, Evans CW, Bottaro M, Ghigliotti L, Cutroneo L, Pisano E (2012a) A nursery area for the Antarctic silverfish Pleuragramma antarcticum at Terra Nova Bay (Ross Sea): first estimate of distribution and abundance of eggs and larvae under the seasonal seaice. Polar Biol 35:1573-1585

Vacchi M, Koubbi P, Ghigliotti L, Pisano E (2012b) Sea-ice interactions with polar fish: focus on the Antarctic silverfish life history. In: Prisco G, Verde C (eds) Adaption and evolution in marine environments, Vol 1: from Pole to Pole. Springer-Verlag, Berlin, p 51-73

Weber LH, El-Sayed SZ (1985) Spatial variability of phytoplankton and the distribution and abundance of krill in the Indian sector of the Southern Ocean. In: Siegfried WR, Condy PR, Laws RM (eds) Antarctic nutrient cycles and food webs. Springer, Berlin, p 284-293

Weber LH, El-Sayed SZ, Hampton I (1986) The variance spectra of phytoplankton, krill and water temperature in the Antarctic Ocean south of Africa. Deep-Sea Res A 33: 1327-1343

White MG, Piatkowski U (1993) Abundance, horizontal and vertical distribution of fish in the Weddell Sea micronekton. Polar Biol 13:41-53

Wiebe PH, Ashjian CJ, Lawson GL, Piñones A, Copley NJ (2011) Horizontal and vertical distribution of euphausiid species on the western Antarctic Peninsula U.S. GLOBEC Southern Ocean study site. Deep-Sea Res II 58:1630-1651

Witek Z, Kalinowski J, Grelowski A, Wolnomiejski N (1981) Studies of aggregations of krill (Euphausia superba). Meeresforsch 28:228-243

Witek Z, Kalinowski J, Grelowski A (1988) Formation of Antarctic krill concentrations in relation to hydrodynamic processes and social behavior. In: Sahrhage D (ed) Antarctic Ocean and resource variability. Springer, Berlin, p 237-244

Woehler EJ (1993) The distribution and abundance of Antarctic and Subantarctic penguins. Scientific Committee for Antarctic research, Cambridge

Submitted: May 12, 2017; Accepted: September 25, 2017

Proofs received from author(s): November 20, 2017 